\title{
Multi-risk assessment in a historical city
}

\author{
C. Arrighi ${ }^{1}$ (D) M. Tanganelli ${ }^{2} \cdot$ M. T. Cristofaro ${ }^{2} \cdot$ V. Cardinali ${ }^{2} \cdot$ A. Marra ${ }^{1} \cdot$ F. Castelli ${ }^{1}$. \\ M. De Stefano ${ }^{2}$
}

Received: 19 March 2021 / Accepted: 23 November 2021

(C) The Author(s) 2021

\begin{abstract}
Natural hazards pose a significant threat to historical cities which have an authentic and universal value for mankind. This study aims at codifying a multi-risk workflow for seismic and flood hazards, for site-scale applications in historical cities, which provides the Average Annual Loss for buildings within a coherent multi-exposure and multi-vulnerability framework. The proposed methodology includes a multi-risk correlation and joint probability analysis to identify the role of urban development in re-shaping risk components in historical contexts. The workflow is unified by exposure modelling which adopts the same assumptions and parameters. Seismic vulnerability is modelled through an empirical approach by assigning to each building a vulnerability value depending on the European Macroseismic Scale (EMS-98) and modifiers available in literature. Flood vulnerability is modelled by means of stage-damage curves developed for the study area and validated against ex-post damage claims. The method is applied to the city centre of Florence (Italy) listed as UNESCO World Heritage site since 1982. Direct multi-hazard, multi-vulnerability losses are modelled for four probabilistic scenarios. A multi-risk of 3.15 M€/year is estimated for the current situation. In case of adoption of local mitigation measures like floodproofing of basements and installation of steel tie rods, multi-risk reduces to $1.55 \mathrm{M} € / \mathrm{yr}$. The analysis of multi-risk correlation and joint probability distribution shows that the historical evolution of the city centre, from the roman castrum followed by rebuilding in the Middle Ages, the late XIX century and the post WWII, has significantly affected multi-risk in the area. Three identified portions of the study area with a different multi-risk spatial probability distribution highlight that the urban development of the historical city influenced the flood hazard and the seismic vulnerability. The presented multi-risk workflow could be applied to other historical cities and further extended to other natural hazards.
\end{abstract}

Keywords Flood risk $\cdot$ Multi-hazard $\cdot$ Multi-vulnerability $\cdot$ Risk management $\cdot$ Seismic risk

C. Arrighi

chiara.arrighi@unifi.it

1 Dipartimento di Ingegneria Civile e Ambientale (DICEA), Università degli Studi di Firenze, 50121 Florence, Italy

2 Dipartimento di Architettura (DiDA), Università degli Studi di Firenze, 50121 Florence, Italy 


\section{Introduction}

Natural hazards pose serious threats worldwide, causing monetary losses, disruption of services and fatalities. Only in 2019, 820 events were registered in the NatCatSERVICE database (Munich 2020). Of these, $7 \%$ were earthquakes, and $45 \%$ floods, flash floods and landslides (Munich 2020; Shahri and Moud 2021). Every year disaster cost the global economy US\$ 520 billion (UNISDR 2018). Economic losses caused by natural hazards are increasing and climate change and urbanization prospects foresee a worsening of risks in the next decades (Dottori et al. 2018). The Sendai Framework for disaster risk reduction advocates for the substantial reduction of disaster risk with the priority being the understanding of risk to improve the prevention, mitigation, and preparedness actions (UNDRR 2015; Ferreira et al. 2020).

The interest in the concept of multi-hazard was first made in the Agenda 21 Conference in Rio de Janeiro (UNEP 1994) that started to advocate for a complete multi-hazard approach for disaster management and risk reduction. In the last decade, the interest in analysing also the multiple risks generated by different hazards has been increasing (Deierlein and Zsarnóczay 2021; Girgin et al. 2019; Terzi et al. 2019; Gardoni and LaFave 2016; Sutley et al. 2017; Marzocchi et al. 2012; Kappes et al. 2012a; Garcia-Aristizabal and Marzocchi 2011). The multi-risk concept is based on: (1) multi-hazard, i.e. the probability of occurrence of multiple hazards in time and space and associated magnitude (Aksha et al. 2020; Tilloy et al. 2019; Goda and de Risi 2018; Araya-Munoz et al. 2017; Kappes et al. 2010; Marzocchi et al. 2012) and (2) multi-vulnerability, i.e. the adverse impacts of multiple hazards in physical and monetary terms (Koks et al. 2019; Ciurean et al. 2013; Marzocchi et al. 2012; Schmidt et al. 2011; Hufschmidt and Glade 2010; Carpignano et al. 2009) thus includes the potential hazards, the exposed targets and their degree of damage/loss (Gallina et al. 2016; Komendantova et al. 2014).

Multi-vulnerability might consider different exposed elements or different susceptibilities of the same element according to different types of hazards. Gallina et al. (2016) recognize two types of analysis: (1) the multi-hazard risk assessment, where vulnerability is independent from a specific hazard, and (2) the multi-risk assessment, comprising both multi-hazard and multi-vulnerability concepts. In the second approach risks are analysed separately (i.e. considering hazard-specific exposures and vulnerabilities) and then aggregated in a multi-risk perspective (e.g. multi-risk index) (SEC 2010). Besides the theoretical frameworks, quantitative applications of multi-risk assessment in historical cities are rarely found in literature (Grünthal et al. 2006). The multi-disciplinarity of these studies requires several expertize and efforts in combining different definitions of exposure, vulnerability, and hazard in a coherent framework (Gill and Malamud 2014). Moreover, many contemporary cities are characterized by historical and urbanistic evolution of districts, with the juxtaposition of many different building types, which make the multi-risk applications more complicated. Namely, the historical centres constitute the core of the urban expansions, denoted by denser and multi-functional planning. Then, different quarters and external outskirts can be found, often characterized by uni-functional activities (e.g. residential, industrial, etc.).

Some works are limited to exposure to multiple hazards or multi-hazard indices (Aksha et al. 2020; Yousefi et al. 2020; Pourghasemi et al., 2020; Rahmati et al. 2019) or focus on multi-hazard, multi-vulnerability applications in coastlines (e.g. Goda and De Risi 2018; Gallina et al. 2020) or mountainous regions (e.g. Yousefi et al. 2020; Terzi et al. 2019). Comprehensive review articles regarding the multi-risk perspectives are published 
in literature (Julià \& Ferreira 2021; Ward et al. 2020; Tilloy et al. 2019; Gallina et al. 2016; Kappes et al. 2012a; Garcia-Aristizabal \& Marzocchi 2011). Otherwise, risk sources have been discussed separately for the same referred areas without explicit focus on multi-risk purposes. In Portugal, several contributions dealing with different hazard sources (i.e. seismic, flood, and fire risks) for the historical centres have been separately developed for emergency planning (Bernardini and Ferreira 2020; Granda and Ferreira 2019; Miranda and Ferreira 2019; Vicente et al. 2011).

The preservation of historical sites and cultural heritage are considered of paramount importance for their intangible aesthetic, historical, spiritual and social value recognized as a pillar of community identity and resilience and for the profitable economic activities associated to them (Appiotti et al. 2020). For some cultural sites single-hazard risk analysis with proposed adaptation strategies are available (Blyth et al. 2020; Milosevic et al. 2020; Chieffo et al. 2019; Porebska et al. 2019; Cara et al. 2018; Reimann 2018; Arrighi et al. 2018; Fatoric and Seekamp 2017; Ferreira et al. 2016; Vojinovic et al. 2016; Maio et al. 2015; Ferreira et al. 2013; Vicente et al. 2011; Lantada et al. 2010; D’Ayala et al. 1997). Recently seismic risk of single monuments (UNESCO Cultural Heritage) has been studied by Despotaki et al. (2018). Flood hazard to cultural heritage has been considered in recent years, mostly with national-scale qualitative approaches (Garrote et al. 2020; Figuereido et al. 2019) or limited to hazard and exposure assessment (Liu et al. 2019; Reimann et al. 2018). In many applications, GIS databases have been widely used in the last twenty years to manage complex environments and gathering several information (Cardinali et al. 2020; Catulo et al. 2018; Cavaleri et al. 2017). GIS are useful to produce risk scenarios and damage maps (Annis et al. 2020; Arrighi \& Campo 2019; Saidi et al. 2019; Dottori et al. 2017; Karimzadeh et al. 2014; Hassanzadeh et al. 2013).

Although multi-risk assessment is recognized as crucial to tackle multiple natural phenomena and vulnerabilities, multi-risk applications suffer from a difficult identification of common metrics to properly compare vulnerability and potential damages (De Ruiter et al. 2017), thus there are few examples in literature especially in historical contexts (Julià \& Ferreira 2021; D’Ayala et al. 2006).

Historical cities recognized as cultural heritage must be protected by natural hazards to preserve their universal value with sustainable adaptation strategies (Galloway et al. 2020; Reimann et al. 2018; Porebska et al. 2019; Sesana et al. 2018) and thus should require a careful evaluation of multiple exposures and vulnerabilities to hazards (Paupério et al. 2012).

The main aim of this work is to propose a multi-risk workflow which includes a multihazard (flood and seismic), multi-vulnerability (of buildings to both hazards) framework for site-scale applications. This study combines the two risks in a consistent GIS framework by sharing common data and approaches to fill the gaps of the studies which assess the risks one at a time, with the adoption of different hypothesis for exposure and vulnerability eventually not comparable with each other. The use of a coherent multi-risk workflow provides more understandable results, which facilitate the public stakeholders in the selection of targeted mitigation interventions. The presented methodology includes a joint probability analysis capable of describing spatial multi-risk correlations, which are rarely examined in literature, but play a crucial role in historical contexts. The multi-risk method is applied to the most ancient portion of the historical centre of Florence (Italy) for the current situation and with the adoption of mitigation measures. This work does not focus on the monumental buildings because their exceptionality cannot be ascribable to generic damage classes neither in terms of behaviour, nor in terms of exposure value quantifications or vulnerability indices. Their assessment needs specific and accurate analysis 
supported by targeted acquisition campaigns and local historical studies (Caprili et al. 2017; Napolitano et al. 2019; De Stefano and Cristofaro 2020).

\section{Multi-risk methodology}

The multi-risk method here introduced combines a multi-hazard (seismic and flood) and multi-vulnerability analysis to both hazards of single buildings within a site-scale approach based on GIS for spatial data and results management. The analysis is carried out at site scale, i.e. the loss of the single building due to natural hazards has been evaluated by means of empirical methodologies considering the typical structural characteristics, materials, vulnerability parameters, etc., without explicit simulation of seismic/flood destructive actions on the assets. Site scale means also that exposure parameters have been inferred based on the knowledge of the average characteristics of buildings in the area. For example, market values of apartments vary depending on numerous factors, but here the average market value for the historical district has been used. Seismic hazard and flood hazard are here treated as independent natural phenomena from a probabilistic point of view. Although an earthquake might induce the collapse of bridges or levees this probability can be considered irrelevant and not contextualized to the case study. The exposure of buildings has been used as a unifying layer for floods and earthquakes to compare scenario losses and multi-risk. Multi-risk is here defined as the frequency weighted sum of damage for the full range of possible hazard events with the specific vulnerability associated to each hazard, i.e. the average annual loss (AAL) caused by multiple sources of hazard and associated direct impacts.

Figure 1 summarizes the methodological workflow which leads to the unifying multirisk AAL. Hazard, exposure and vulnerability data have been collected in a coherent path, although separately analysed. The two analyses, for seismicity and riverine floods follow simultaneous steps. Both flood and seismic hazard are described by the probability of occurrence of the event (or return period Tr), but they differ with respect to their intensity measures. For floods, a key role is played by the inundation extents and water depth. For earthquakes, the Peak Ground Acceleration (PGA) converted to the macroseismic intensity (EMS-98) has been assumed as the intensity measure.

Exposure analysis exploits the same cartographic 1:2000 scale layer of buildings and market values for both hazards with a distinction on the portions of the building potentially affected (Sect. 2.2). For each probabilistic scenario, the physical and monetary losses are computed and finally AAL is evaluated as the integral of the damage-frequency curve (USACE 1989). The total AAL produced by the damages caused by floods and earthquakes is the main descriptor of the multi-risk problem. Let us consider the two random variables in space $\mathrm{AAL}_{\mathrm{f}}$ and $\mathrm{AAL}_{\mathrm{e}}$, which represent the annual losses due to flood and earthquake, respectively. The total annual $\mathrm{AAL}_{\mathrm{t}}$ is given by the sum of the two random variables:

$$
\mathrm{AAL}_{t}=\mathrm{AAL}_{f}+\mathrm{AAL}_{e}
$$

It is known that the mean value of the sum of two random variables is just the sum of their mean values, i.e.

$$
E\left[\mathrm{AAL}_{t}\right]=E\left[\mathrm{AAL}_{f}\right]+E\left[\mathrm{AAL}_{e}\right]
$$




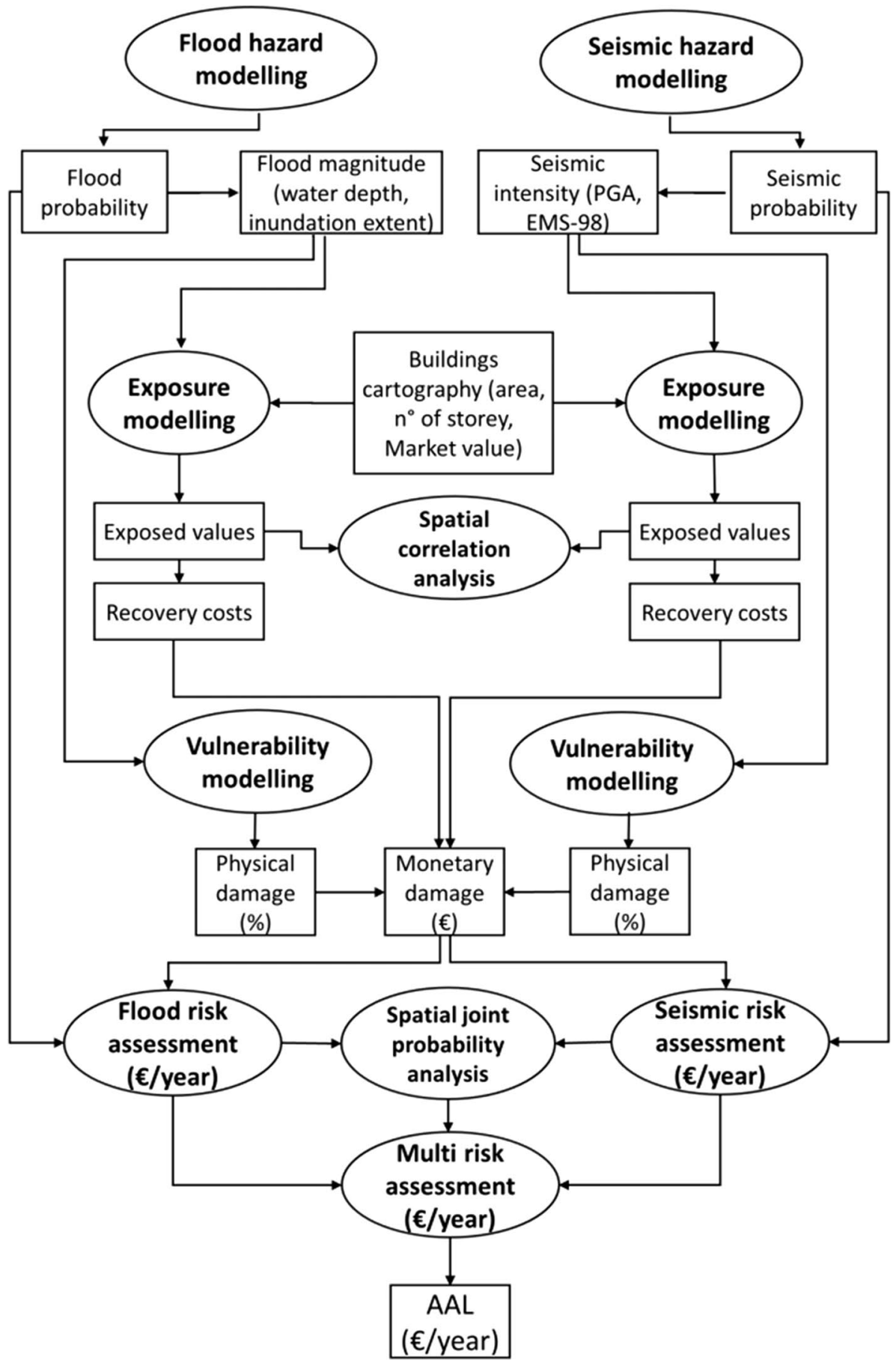

Fig. 1 Multi-risk methodological flowchart highlighting the use of the same exposure layer, spatial correlation and joint probability analyses 
which means that, starting from the AAL of the single hazards, the total average annual loss can be obtained in a straightforward manner by summing the two mean values. To have a complete description of the statistical behaviour of the total annual cost, a probability distribution is needed. In the present problem, since the two random hazard variables are independent (the occurrence of floods is not related at all to that of the earthquakes and viceversa), the probability density function (PDF) of the total annual cost can be defined according to the following expression:

$$
f_{\mathrm{AAL}_{\mathrm{t}}}\left(\mathrm{AAL}_{\mathrm{t}}\right)=\int_{-\infty}^{\infty} f_{\mathrm{AAL}_{\mathrm{e}}}\left(\mathrm{AAL}_{t}-\mathrm{AAL}_{f}\right) f_{\mathrm{AAL}_{\mathrm{f}}}\left(\mathrm{AAL}_{f}\right) \mathrm{dAAL}_{f}
$$

where $\mathrm{f}_{\mathrm{AAL}}$ represents the PDF of the random variable $\mathrm{AAL}_{e}$ (earthquake annual loss), and $\mathrm{f}_{\mathrm{AALf}}$ is the PDF of the random variable $\mathrm{AAL}_{f}$ (flood annual loss). Once the PDF of the total annual cost is known, any other distribution can be obtained in a straightforward manner and then compared with the single-risk analysis curves.

Given the interest in the role of urban evolution of historical cities, spatial correlations of flood and seismic exposures and vulnerabilities are evaluated at single-building level for homogeneous building groups, i.e. buildings constructed in the same period. Multirisk is further investigated by describing the dependence of the spatially random variables $\mathrm{AAL}_{e}$ and $\mathrm{AAL}_{f}$. Copulas are multivariate cumulative distribution functions widely used in probability, statistics, and hydrology (Salvadori et al. 2016, 2011, 2004) based on Sklar's Theorem (1959). The latter states that any multivariate joint distribution can be written in terms of univariate marginal distribution functions and a copula which describes the dependence structure between the variables. The steps involved in this analysis for historically homogeneous building groups are: (1) identification of the marginal distributions of $\mathrm{AAL}_{e}$ and $\mathrm{AAL}_{f}$, (2) identification of the copula family best describing the dependency between $\mathrm{AAL}_{e}$ and $\mathrm{AAL}_{f}$, (3) estimation of the parameters of the copula function based on maximum likelihood criterion, (4) selection of the best fitting copula based on Akaike and Bayesian information criteria.

Tested marginal distributions of step (1) are normal, log-normal, Gumbel, Frechet, GEV, P3. Forty families of copula functions are tested in step (3) by using the R Packages "copula" (Hofert et al. 2020) and "nsRFA" (Centre for Ecology \& Hydrology 1999; Viglione et al. 2007).

\subsection{Multi-hazard assessment}

National and International codes set the strategies for the seismic and flood risk reduction (EN 1998-1, 2004, FEMA-356 2000; Directive 60/2007/EC).

The seismic hazard of the study area is identified by the National classifications provided by the INGV (Stucchi et al. 2004), which provide a seismic hazard map for the Italian territory referred to stiff soils expressed in terms of horizontal soil acceleration with a probability of exceedance of $10 \%$ in 50 years. This classification has been later adopted by the National Codes (NTC 2018). For each area of the Italian territory the seismic design action is based on this map, which also accounts for the soil characteristics at local level.

Formulations published in literature are adopted to define the seismic hazard in terms of macroseismic intensity (Grünthal 1998). Starting from the seismic hazard of the area under study, the PGA obtained for each $\mathrm{Tr}$ is converted to the associated macroseismic intensity (I) as defined in Margottini et al. (1992). Many of these laws in literature can be traced back to the same equation as presented by Lagomarsino and Giovinazzi (2006) i.e. 


$$
a_{g}=C_{1} C_{2}^{(I-5)}
$$

in which PGA is denoted by $a_{g}, C_{1}$ and $C_{2}$ are the two coefficients, the latter raised to the difference between the macroseismic intensity level $I$ and a value equal to 5 . The two coefficients are 0.04 and 1.65 , respectively.

Concerning the flood hazard, the EU "Floods" Directive (60/2007/EC) requires member states to produce flood hazard maps at river district level showing flood extent and magnitude (i.e. expected water depths) for low, medium and high probability scenarios. The District of the Northern Apennines is the authority responsible for issuing flood hazard maps in the study area, which are open available and used in this study. Four occurrence probability scenarios are mapped, i.e. $\operatorname{Tr} 30,100,200$ - and 500-year.

Flood depths are computed by coupling a 1D river model with a system of interconnected storage cells in the floodplain described by a metre scale LiDAR-derived Digital Terrain Model. For more detailed information on the hydraulic model, please see (Arrighi et al. 2018).

\subsection{Multi-exposure model}

The exposure is referred to the position and the monetary value of buildings located in the hazard prone area (Papilloud et al. 2020). For both floods and seismic hazards, the exposure is identified by means of the Regional Technical Cartography scale 1:2000 which provides footprint area, perimeter and elevation of buildings.

Monetary exposure is obtained by combining footprint area $A_{f}$ and market values $M_{V}$ available at sub-municipal scale (Agenzia delle Entrate-OMI 2019) according to the following equation:

$$
E_{M}=M_{V} \times A_{f} \times n
$$

where $n$ is the number of affected storeys. For seismic hazard, $n$ coincides with the total number of overground storeys. For flood hazard, $n$ depends on the flood depths and for flat floodplains usually includes basement and ground floor (i.e. water depth lower than 4-5 m). The parameter $n$ is associated with each building based on fast surveys with Google Street view. Market value of basements and cellars is assumed equal to one fourth of $M_{V}$.

Repair cost $R_{C}$ is the cost of restoring/renovating the pre-existing condition of the building (e.g. strengthening solutions, plastering, etc.). $R_{C}$ is assumed as a fraction (20\%) of the market value which corresponds to the average difference between the market value of new buildings and that of equivalent older buildings requiring renovation (Arrighi et al. 2013).

$$
R_{C}=E_{M} \times 0.2
$$

This value is a proxy that reflects a balance between the two opposite extreme behaviours of buyers (which, in turn, depend on their financial resources): i.e. completely renovate the building or bringing the building back to a minimum level of functioning (Molinari et al. 2020).

Although this value can underestimate renovation costs for an historical area subject to several architectural and normative constraints, it has been validated in other Italian contexts where damage data were available. Seismic repair costs have been correlated to the damage index percentages obtained by the forecasted damage scenarios by means of 
percentage $R_{C}$. These values have been assumed by the Sismabonus documentation (MIT 2017).

\subsection{Multi-vulnerability model}

Vulnerability models express the likelihood that assets at risk will sustain varying degrees of loss over a range of hazard intensities (Galasso et al. 2021). Due to the intrinsic differences of the two hazards intensity measures, i.e. flood depth and macroseismic intensity, and damage mechanisms of the buildings, the vulnerability models are separately defined (see Sects. 2.3.1 and 2.3.2). Although the flood and seismic vulnerabilities rely on different theoretical backgrounds, their assessment brings to the same metrics that are (1) a physical damage expressed in relative per cent loss with respect to the whole exposure and (2) a monetary damage expressed in $€ / \mathrm{m}^{2}$ of building footprint for each hazard probabilistic scenario.

\subsubsection{Seismic vulnerability}

The seismic vulnerability of the buildings has been investigated adopting the procedure developed by Giovinazzi and Lagomarsino (2004) according to the macroseismic classification proposed by Grunthal (1998). This methodology, calibrated on the evidence of damage scenarios from past earthquakes in European contexts has been widely used in the last decades. It conceives an empirical approach based on the proposal of several modifiers. The starting point of the procedure is given by the building classification adopting a macroscale approach.

This classification is made both for masonry buildings and reinforced concrete structures. Depending on the characteristics of the structural model, a basic Vulnerability index $V_{I} *$ is assigned. This value has been calibrated for different technique typologies based on the statistical data from the ex-post damages. Then, the initial values can be altered; 12 parameters are involved, regarding the state of preservation of the buildings, the number of floors, the thickness of the bearing walls, the irregularity, the superimposed floors, the roof structures, etc. Finally, a Vulnerability index V is expressed as:

$$
V=V_{I}^{*}+\Delta V_{m}
$$

, where $\Delta V_{m}$ is given by the sum of the different contribution of the modifiers influencing the seismic behaviour of the construction. 424 masonry buildings and $21 \mathrm{RC}$ structures have been identified. Within the masonry buildings, two classes have been distinguished; they can be divided into Simple Stone (M3) and Unreinforced masonry (M5). The damage index $\left(\mu_{D}\right)$ has been finally correlated with the vulnerability one through the hyperbolic tangent of an expression combining the seismic intensity I with $\mathrm{V}$ index and a ductility index Q:

$$
\mu_{D}=2.5\left[1+\tanh \left(\frac{I+6.25 V-13.1}{Q}\right)\right], 0<\mu_{D}<5
$$

According to Lagomarsino (2006) Q has been assumed equal to 2.3. The Hyperbolic curve expresses the most-likely vulnerability index for the different seismic intensity levels, ranging between 0 and 12. The values of the damage index $\mu_{\mathrm{D}}$ range between 0 to 5 , 
which correspond to specific Damage Levels DLs. Namely, the following DLs are defined by the total amount of damage inside a selected building, from DL0 — no damage, DL1negligible to slight damage, DL2-moderate damage, DL3-substantial to heavy damage, DL4-very heavy damage, DL5-Collapse. For different classes of buildings, given a damage value $\mu_{\mathrm{D}}$ the percentage of recovery costs $R_{\mathrm{C}, \mathrm{DL}}$ is obtained. According to Cosenza et al. (2018), the $R_{C, \mathrm{DL}}$ for the different limit states have been assumed from the Sismabonus documentation (i.e. 80, 50, 15 and 7\% for SLC, SLV, SLD and SLO, respectively).

\subsubsection{Flood vulnerability}

The most used approach for the assessment of flood vulnerability is the use of stage-damage curves, which relate a certain water depth (metres above ground) to an expected degree of loss in relative or absolute terms (Galasso et al. 2021; Molinari et al. 2020; Garrote et al. 2019; Carisi et al. 2018; Laudan 2017; Notaro et al. 2014; Merz et al. 2010).

The flood vulnerability model here adopted is a synthetic model which firstly associates a relative physical damage $D_{\%}$ to flood depth in metres $h$ and then calculates a monetary damage as a function of the recovery cost $R_{\mathrm{C}}$ (Eq. 5) (Arrighi et al. 2018). The relative damage is calculated through a piecewise linear stage-damage curve for buildings with basement:

$$
D_{\%}(h)= \begin{cases}52 \cdot h-7, & 0.25 \leq h<1.5 \\ 14.5 \cdot h+49.25, & 1.5 \leq h \leq 3.5\end{cases}
$$

The model was created based on expert judgement for the city of Florence (Italy) and applied both at building and census block scale (Arrighi et al. 2013, 2018). It has been validated through comparison with other validated models and ex-post damage claims in other Italian contexts (Scorzini and Frank 2015; Molinari et al. 2020).

\subsection{Multi-risk mitigation}

In this work only mitigation measures are considered for multi-risk reduction. Although flood risk could be reduced through prevention (e.g. retention basins), it is not considered here to present common and coherent expectations within the two risks. Furthermore, the limited scale of the study area drives mostly towards the use of mitigation interventions since the prevention measures are generally designed at basin scale to reduce flood hazard in wider areas.

Within a multi-risk perspective, an optimal mitigation strategy would be to design and implement actions capable of targeting multiple hazards, i.e. earthquakes and floods. An example of multi-risk intervention could be the elevation of building equipped with seismic isolation devices which would act (1) to reduce flood exposure by raising the ground floor and (2) to reduce base shear and displacement decoupling the buildings from the ground movement.

However, to the authors knowledge, such a strategy has never been applied to a whole historical city centre and cost is likely to be prohibitive. Mitigation scenarios are thus simulated for each single hazard.

Referring to the seismic mitigation interventions, the Italian building codes are targeted to the building level. They recognize three different levels of strengthening: the local interventions, the seismic improvements, and the seismic compliance to the current regulations 
(NTC 2018). It is worth noting that, dealing with an urban scale, the accuracy of the last two solutions requires specific computations not addressed to the scale of interest of this work. Furthermore, extensive application of local interventions can lead to significant improvements of the seismic vulnerability of buildings. In this paper, local interventions have been considered in order to reassess $V$ and run the risk model in a mitigated scenario. The effectiveness of the repairs has been estimated through a macroseismic approach by cutting down the vulnerability modifiers $\Delta V_{m}$.

For flood risk mitigation the focus is on those strategies private owners can afford to reduce residual risk, such as the building waterproofing. National guidelines and standards in this field are not available in Italy and although many retrofitting strategies exist (e.g. relocation, levee and floodwall protection, demolition etc.) only dry waterproofing is here considered as applicable for an historical city centre.

The waterproofing of the building basement mainly consists in (1) installing backflow valves to prevent water entering from the sewerage system and (2) installing flood gates or barriers on the basement windows, i.e. sealing home's exterior walls.

For simulating the risk mitigation scenario, the flood vulnerability curve has been modified to account for the waterproofing of the building basement, i.e. a zero-damage threshold has been set for $h$ equal to $0.25 \mathrm{~m}$.

$$
D_{\%}(h)= \begin{cases}52 \cdot h-13, & 0.25 \leq h<1.5 \\ 17.5 \cdot h+38.75, & 1.5 \leq h \leq 3.5\end{cases}
$$

\section{The historical centre of Florence}

Florence (Italy) is one of the world's great treasures in art, culture, and Renaissance history. It is a UNESCO World Heritage site for its integrity, authenticity, and Outstanding Universal Value since 1982. The historic centre of Florence was born as the Roman colony of Florentia (founded in $59 \mathrm{BC}$ ). The city grew during the Middle Ages when several of its monuments were erected. It finally became a symbol of the Renaissance during the early Medici period (between the 15th and the sixteenth centuries), reaching extraordinary levels of economic and cultural development.

The study area is the portion of the historic centre inside the fourth town walls, built in 1172 (Fig. 2a, b, boundary polygon). It has been selected because buildings underwent limited structural interventions and more recent urban developments are easily identified. The area comprises the old Roman urban frame (Fig. 2b black dashed line), plus a boundary area delimited by the Arno river (South). The urban layout keeps settled over the old Roman configuration following the cardo and decumanus grid (Pegna 1974). The buildings of the area are mostly masonry structures. The majority was erected over Roman foundations, nevertheless, different alterations in the height of the structures occurred during the years. A series of renovations concerning demolitions and reconstructions occurred in the central area of Piazza della Repubblica in the XIX century (Fig. 2, panel b green buildings) when Florence temporarily served as Capital of Italy in 1865. Other alterations occurred after WWII, when the Nazist army bombed several structures around the Ponte Vecchio. These buildings have been replaced in the following decades by reinforced concrete (RC) structures (Fig. 2, panel b yellow buildings). The oldest buildings (Fig. 2, panel b blue buildings) include the Medieval constructions, with the presence of tower houses and masonry building aggregates. During the years most parts of the buildings in the area 

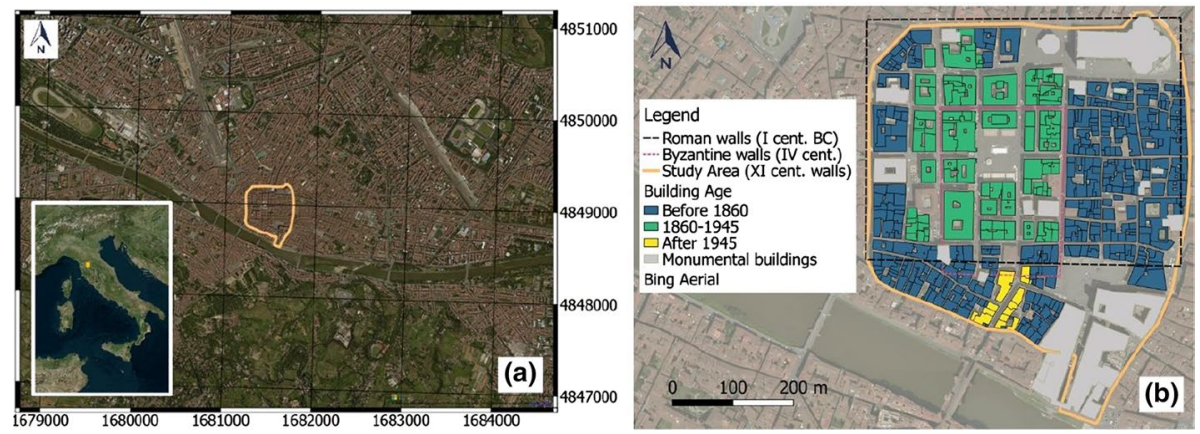

Fig. 2 Geographic setting of the study area (a) (EPSG 3003 Monte Mario Italy 1) and detail of Roman, Byzantine and medieval walls with the historical periodization of the building units (b) (source buildings shapefile: Regione Toscana cartographic portal; background map: Bing Aerial)

underwent several alterations, superimposition of floors, etc. Nowadays the city centre hosts commercial and touristic activities with a small percentage of residences; new openings and connections between the structural units were made, merging the internal structures or subdividing them. Examples of building types in the study area are available in the supplementary materials. Finally, the monumental buildings of the area (Fig. 2, panel b grey buildings) point out the huge number of relevant structures in such a small area. These buildings are masonry structures and include public palaces and religious buildings.

\subsection{Earthquakes and floods in Florence}

During the centuries, a relevant number of floods and earthquakes occurred. For both the hazard sources, historical data are collected since the XII century. More than 140 seismic events with an intensity greater than V on the Mercalli-Cancani-Sieberg (MCS) scale and 56 floods occurred (Molin and Paciello 1999; Rovida et al. 2016, Losacco 1967). Despite their numerosity, only two earthquakes led to significant damage in the city, turning out that the floods represented so far, the most significant hazard. Starting from 1177, almost once in a century Florence was hit by a damaging flood event. The most catastrophic flood was registered in 1333, when all the bridges collapsed. 120 years later, in 1453, an earthquake intensity of 7 on the MCS scale hit the area. It did not provoke collapse of structures, but some damage was suffered, also by monuments. Hence, a series of floods struck the cities; the main ones are recorded in 1547 , $1557,1589,1740,1758,1844$. In 1895, the so-called "Florence great earthquake" estimated as a grade 7 of the MCS scale caused extensive damage to the city (Vannucci et al. 1999). No major collapse occurred, but several buildings and most of the monuments, churches and historic buildings suffered minor damages and small failures (Guidoboni 2018). Finally, the last important event was the 1966 flood which caused 38 deaths in Florence and its province, severe damage to many of its most precious art works and threatened the economic and social viability of the city and its residents (Galloway et al. 2017), causing a great emotional impact also in the international community (Kumar 2020; Nencini 1966). For its elevation characteristics, the most affected area in 1966 was the Santa Croce neighbourhood (outside the study area), with flood depths of the order of 4-5 $\mathrm{m}$. The ancient nucleus of the city (the study area) was also 
affected with water depths lower than $2 \mathrm{~m}$, according to the elevation of historical marble plates. Although the seismic and flood risks in the city of Florence have been separately investigated in the past, they have been carried out at different spatial scales or excluded this portion of the historical city (D’Agostino et al., 2019; Arrighi et al. 2018; Ripepe et al. 2018, 2015; Matassoni et al. 2017; SISMED 2016, Lacanna et al. 2016).

\subsection{Seismic and flood risk reduction in Florence}

Many strategies have been implemented to manage the risks affecting the city, by addressing both prevention and mitigation. Namely, the prevention refers to the reduction of hazard, while the mitigation concerns the abatement of impacts, i.e. the reduction of vulnerability and exposure. Prevention is usually carried out at territory/catchment scale. On the other side, the mitigation strategies are localized and referred to the building scale.

Concerning the seismic risk, only mitigation strategies can be promoted. To this aim, during the past years, no explicit policies were developed for the city centre of Florence. Several strengthening solutions and localized interventions were done by owners and private investors, but their numbers are not entirely known. They concerned the insertion of steel tie rods to prevent local mechanisms, strengthening applications to the masonry walls (injections or RC external layers), as solutions targeted to stiffen the horizontal diaphragms (slabs and vaults). It is worth noting that these interventions, despite their practical utility, if randomly applied to the different apartments without a conscious assessment at the building scale, can lead to irregular stiffness distributions highlighting the failure probabilities of certain parts under seismic excitement. Starting from 2017 the Italian Governments are releasing acts aimed at the seismic risk reduction of residential buildings, promoting tax reliefs and cost absorptions for condominiums by encouraging strengthening interventions for the improvements of the seismic performances.

After the 1966 flood in Florence, flood prevention works and policies were proposed, and some were carried out, but they were not part of a comprehensive plan (Galloway et al. 2020). The only significant intervention was the lowering of the aprons of bridges in 1980, which increased the conveyance capacity of the Arno River in the urban reach. The establishment of the Arno River Basin Authority led to the development in 1996 of the Flood Risk Plan for the Arno Basin which identified the key elements for a successful flood protection strategy: (1) increasing the storage capacity for flood waters upstream of the city, (2) increasing the conveyance capacity of the river, (3) heightening of the levee system and removal of silt deposits from.

existing dams to recover part of the storage, and (4) improving control of and response to flood events. However, only a few of these measures were implemented, most notably the completion around 2000 of the Bilancino Dam which reduced the flood peak flow in Florence by $100-200 \mathrm{~m}^{3} / \mathrm{s}$. Retention basins upstream of the city are currently being concluded and still not operational.

On the side of mitigation, private owners have not been stimulated to adopt retrofitting actions to protect underground and ground storeys. Only some museums in the city are nowadays testing the use of inflatable levees in collaboration with the municipal Civil Protection Office. Thus, Florence remains at risk to significant flooding (low-probability, high-magnitude events) since the current level of protection does not yet provide 
the risk reduction needed for a city with such exemplary characteristics (Arrighi et al. 2018; Galloway et al. 2020).

\section{Application and results}

\subsection{Data sources}

The first part of the application of the multi-risk assessment method to the case study is the gathering and cataloguing of GIS data and the enrichment of the feature attributes for exposure and vulnerability modelling. Geographic data have been merged in the open-source QGIS environment through raster zonal statistics or spatial joins. 560 buildings are located in the study area. The main source of exposure data is the Regional Technical Cartography (Regione Toscana) and the apartment census (ISTAT 2011). However, additional data related to exposure and vulnerability were assessed by visual/virtual inspections and included as new shapefile attributes. Although nowadays different automated as semi-automated procedures exist to collect data (Geiß et al. 2017; Wieland et al. 2012), the on-site visual inspections were preferred. This is due to the possibility of observing details not so easy to detect (tie rods within the decorative apparatus of facades), as the expert judgement's need to catch other structural parameters (presence of superimposed levels etc.).

Flood and seismic analyses target different characteristics of the building stock. For the flood risk, the ground floor level and the presence of basements have been

Table 1 GIS data used for the multi-risk analysis and their source

\begin{tabular}{|c|c|c|c|}
\hline Risk component & Data & Description & Source \\
\hline \multirow[t]{2}{*}{ Hazard } & Flood hazard maps & Raster, $1 \mathrm{~m}$ resolution & $\begin{array}{l}\text { Autorità di Bacino Distret- } \\
\text { tuale dell'Appennino } \\
\text { Settentrionale }\end{array}$ \\
\hline & Seismic hazard maps & $\begin{array}{l}\text { Database, square mesh of } 5 \mathrm{~km} \text { on } \\
\text { each side }\end{array}$ & Italian Code NTC (2018) \\
\hline \multirow[t]{4}{*}{ Exposure } & Building footprint & Vector, scale 1:2000 & Regione Toscana \\
\hline & Number of storeys & Vector attribute & Visual inspection \\
\hline & Presence of basement & Vector attribute & Virtual inspection \\
\hline & Market values & Vector & OMI, Agenzia delle Entrate \\
\hline \multirow[t]{8}{*}{ Vulnerability } & Ground floor elevation & Vector attribute & Visual inspection \\
\hline & Construction type & Vector attribute & Visual inspection \\
\hline & Age of the building & Vector attribute & $\begin{array}{l}\text { National Institute of Statis- } \\
\text { tics (ISTAT) apartment } \\
\text { census, (2011) }\end{array}$ \\
\hline & Height of the building & Vector, scale 1:2000 & Regione Toscana \\
\hline & State of conservation & Vector attribute & Visual inspection \\
\hline & Superimposed floors & Vector attribute & Visual inspection \\
\hline & Structural modifiers & $\begin{array}{l}\text { Vector attribute (interaction of the } \\
\text { building and staggered floors) }\end{array}$ & Visual inspection \\
\hline & Aseismic devices & Vector attribute & Visual inspection \\
\hline
\end{tabular}


considered. For the seismic risk, the construction typology, the state of conservation, the presence of superimposed floors, the interactions between the different structural units and the presence of aseismic devices have been checked for vulnerability assessment. Table 1 summarizes the key geospatial data used in the analysis, their format and source.

\subsection{Multi-hazard}

The seismicity of Florence leads to a peak ground acceleration PGA of $0.131 \mathrm{~g}$ for a return period Tr of 475 years and an Importance Class of the structures equal to II (NTC 2018). Micro-zonation information, which describes local amplification factors, is currently under investigation in the study area. The same seismic action has been considered for all the urban stock despite the different importance classes existing in the area. Later, it has been converted to a macroseismic intensity adopting Eq. (4).

According to the official flood hazard mapping (Autorità di Bacino Distrettuale dell'Appennino Settentrionale 2018) the historical city centre of Florence is not exposed to floods with a return period lower than 100 years. This is the result of the series of interventions implemented after the 1966 flood (Sect. 3.2). However, for high recurrence interval scenarios (e.g. 200, 500 years) the study area is affected, especially its easternmost part.
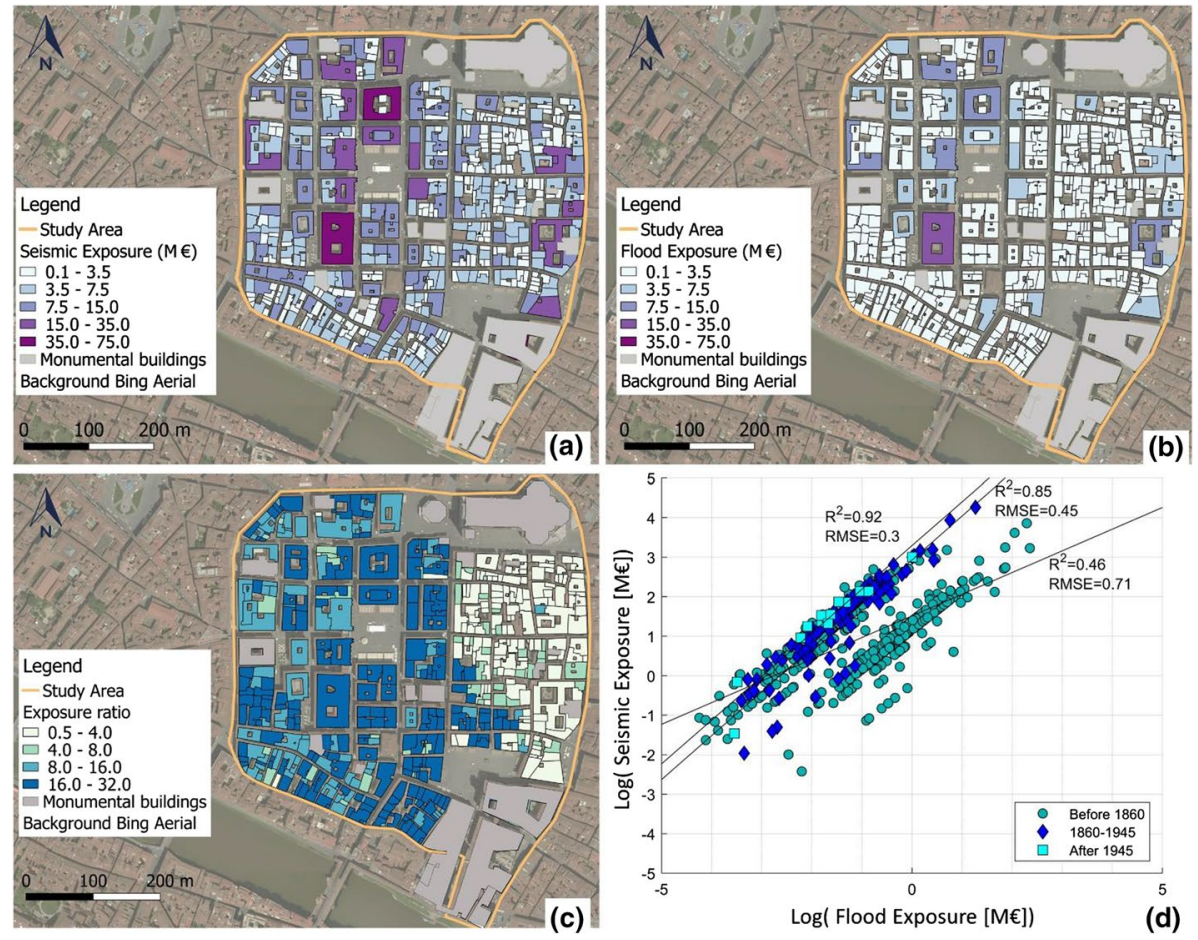

Fig. 3 Monetary exposure to seismic hazard (a) flood hazard (b), and ratio between seismic and flood monetary exposure (c) and multi-exposure correlation in Log-scale (d) (source buildings shapefile: Regione Toscana cartographic portal; background map: Bing Aerial) 
For each probabilistic scenario, average flood depths have been assigned to the buildings through raster zonal statistics.

\subsection{Multi-exposure}

The map of Fig. 3 shows the results of the seismic and flood exposure modelling in the study area based on Eq. 5. As explained in Sect. 1, monumental buildings are not modelled because their value cannot be estimated by using market values. Seismic exposure is way larger than flood exposure because an earthquake affects the whole building while floods affect only the basement and ground floor in the study area. Moreover, historical buildings have an average number of storeys of 4.2, medieval tower houses usually exceed 5 storeys. Seismic exposure is of the order of $4.7 \mathrm{M} €$ and always larger than flood exposure which ranges from 0.1 to $19.2 \mathrm{M} €$ with an average value of $1.4 \mathrm{M} €$. Significant exposure values are obtained for large building footprints of the order of 3500 square metres and more than 4-5 storeys, characterizing modern structures (see also Fig. 2). Since the same market value has been adopted for both hazards (i.e. $M_{\mathrm{V}}=4100 € / \mathrm{m}^{2}, R_{\mathrm{C}}=820 € / \mathrm{m}^{2}$ ), the exposure maps highlight the geometrical characteristics of the urban stock. The slender buildings (e.g. Middle Ages tower houses) have a high exposure to the seismic hazard but not to floods. The relationship between the two sources can vary in case of squat building with large basements. A comparison of panels (a) and (b) in Fig. 3 shows how the area around Piazza della Repubblica (middle of the maps) is more exposed because of the larger footprint areas of the structures; nevertheless, this exposure is well distributed between earthquake and flood risks, pointing out good geometrical relationship between plans and height of the structures. In this area, seismic exposure is dominant over flood exposure. In fact, in this portion of the study area only basements are affected in case of flooding. This is shown in panel (c) where the ratio between seismic and flood exposure is represented. On the other hand, in the Medieval part of the urban stock, i.e. the eastern part, flood exposure becomes more relevant although seismic exposure is still dominant. For some buildings low flood exposure corresponds to highly exposed building for the seismic hazard, which highlights the presence of slender buildings and tower houses. Figure $3 \mathrm{~d}$ shows the correlation among the logarithm of seismic and flood exposure at single-building level for the three periods of construction listed in Fig. 2 (Middle Ages, XIX century and post-war constructions). Generally, the exposure is highly balanced towards the seismic risk. Three distinct regression curves characterize the urban stock. It is worth noting that the buildings dated before the 1860 follow a different trend, while the other two categories seem more aligned along similar slopes. The oldest buildings, which represent also the most numerous class, show the highest dispersion. The coeval constructions present common trends in terms of exposure, such as in spatial terms. This is clearer for the more modern buildings realized after the 1945 ( $R^{2}$ equal to 0.92$)$. On the other side, the buildings realized before the 1860 concern structures coming from different centuries, so following different spatial and geometrical rules.

\subsection{Vulnerability, physical and monetary losses}

The vulnerability procedures described in Sect. 2.3 have been adopted. The seismic vulnerability indices of the investigated stock range between 0.58 and 0.98 . A mean value of 0.77 is obtained, with a coefficient of variation equal to $8.7 \%$. By adopting the modifiers 
by Lagomarsino and Giovinazzi (2006), around $26 \%$ of the buildings gets a lower V index, the $64 \%$ increases their vulnerability and the $10 \%$ is not modified (see Supplementary Figure). Considering the $\mathrm{V}$ indices ranging in Vulnerability classes, the $20 \%$ of the stock has a $\mathrm{V}$ index ranging between 0.6 and 0.7 , while the $80 \%$ presents a high vulnerability class (V index ranging between 0.7 and 0.9). The area around Piazza della Repubblica (middle of Fig. 2), built in the XIX century, is characterized by isolated structures; the medieval aggregates (eastern portion of the map) have more irregular configurations that penalize the seismic vulnerability. For the computation of the seismic vulnerability, in this work, the
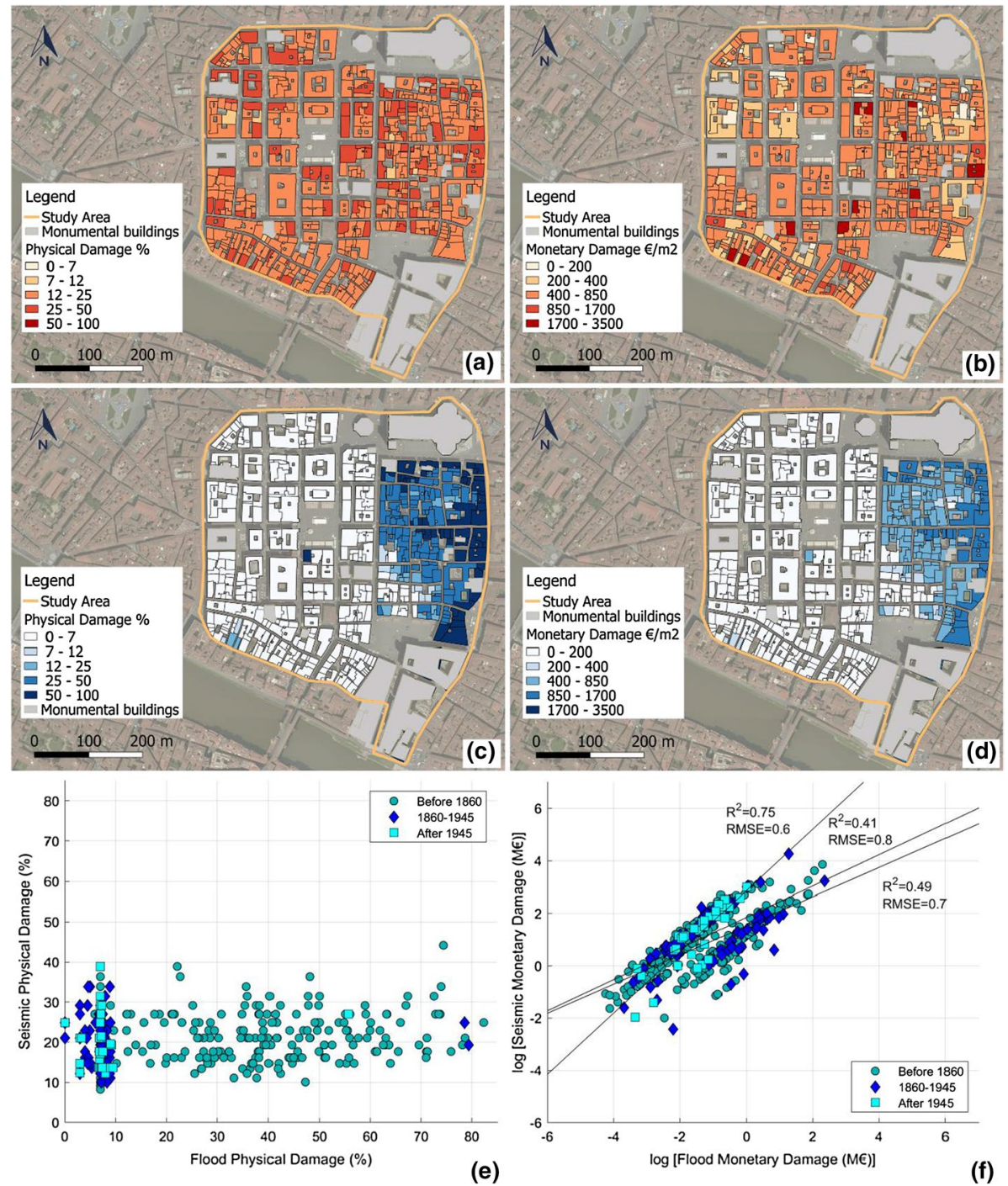

Fig. 4 Physical damage and monetary losses for seismic (a, b) and flood hazard (c, d), correlation among physical damages (e), correlation among monetary damages (f) for a 200 years scenario (source buildings shapefile: Regione Toscana cartographic portal; background map: Bing Aerial) 
presence of aseismic devices such as steel tie rods at different levels of these structures was considered. The investigated buildings present a good state of preservation; moreover, the medium-low number of storeys and the presence of tie rods reduce the intrinsic vulnerability of the stock. Differently, other parameters like the presence of super-imposition levels and staggered floors penalize the vulnerability of the structures.

Figure 4 shows the physical and monetary damage for probabilistic actions with $\mathrm{Tr}$ 200 years. In the area, the distribution of hazard is spatially homogeneous for earthquakes while flood depths may vary significantly according to terrain elevation differences, despite the size of the study area. This yields a quite homogeneous seismic physical damage, mostly driven by vulnerability and exposure, and a clustered physical flood damage.

The seismic physical damage (panel a) is widespread throughout the study area with $74 \%$ in the $12-25$ range, $20 \%$ in the $25-50$ range, $6 \%$ in the $7-12$ range and only $1 \%$ in the 0-7 range. The seismic monetary losses (panel b) are on average of the order of 580 $€ / \mathrm{m}^{2}$ with highest values above $3280 € / \mathrm{m}^{2}$. The overall estimated seismic damage for $\mathrm{Tr}$ 200 years is $74.5 \mathrm{M} €$. It is worth noting that these economic values are referred to the building footprint; hence, the $R_{\mathrm{c}} \mathrm{s}$ herein presented are not subdivided for the number of storeys. Monetary losses represent a significant source of uncertainty in risk analysis (Ahmad et al. 2014); the seismic monetary losses have been compared to the L'Aquila 2009 earthquake repair costs (Dolce and Manfredi 2015). The latter considers the $R_{C} \mathrm{~s}$ by the compilation of the AeDES Sheets (Bernardini et al. 2000) and the expressed judgement of compliance/non-compliance to safety standards. Two different damage classes and $R_{C} \mathrm{~s}$, respectively, have been deduced; they are characterized by $R_{C} \mathrm{~s}$ of $285 € / \mathrm{m}^{2}$, and 837 $€ / \mathrm{m}^{2}$. These values are comparable with the assumptions made in terms of Physical loss (\%), considering the last value equal to the total refurbishment of the buildings. In fact, it would lead to $669 € / \mathrm{m}^{2}$ for the SLC and $418 € / \mathrm{m}^{2}$ for the SLV. They are coherent with the $R_{C, \mathrm{DL}}$ assumed in the presented paper, which correspond to $656 € / \mathrm{m}^{2}$ and $410 € / \mathrm{m}^{2}$ for SLC and SLV, respectively. For the other two LSs, SLO and SLD this paper leads to low values of $R_{C}$ s, equal to $57 € / \mathrm{m}^{2}$ and $123 € / \mathrm{m}^{2}$, respectively. These are not directly comparable with the $\mathrm{R}_{\mathrm{C}} \mathrm{s}$ obtained for L'Aquila event; nevertheless, several uncertainties are involved especially in the correlation vulnerability/damage for the ground motion of L'Aquila, corresponding the event in terms of $\mathrm{Tr}$ for lower earthquakes in a different context.

It is worth noting that for the seismic risk, the area with the less vulnerable buildings (1860-1945) has the highest monetary exposure (see also Fig. 3). Consequently, the earthquake risk tends to distribute homogeneously in the area. The highest seismic monetary losses per unit surface are in the most ancient tower houses disseminated in the historical centre. However, when medieval tower houses are included inside building blocks, they take advantage of neighbour buildings thus have a lower vulnerability. Therefore, the positive and negative consequences of the building cluster aggregation are also pointed out. The presence of adjacent structures can increase or decrease the seismic risk of the buildings; staggered floors and different height configurations tend to increase the vulnerability of the structures, nevertheless, positive contributions are also given, mostly by the support actions of the bordering constructions. This may explain why these medieval buildings in the easternmost part of the study area have a lower risk, while corner buildings are affected by a higher risk.

Considering the flood hazard, the physical damage and the monetary damage distributions are shown in panels (c) and (d), respectively, as a result of Eq. 6. Considering the physical damage, although in the area average flood depths for the probabilistic scenarios are about $0.55 \mathrm{~m}$, only the easternmost portion of the study area is severely affected with depths of the order of 0.6 up to $2 \mathrm{~m}$. The remaining part is mostly characterized by flood 
depths around $0.15-0.3 \mathrm{~m}$ with consequent minor damages to basements only. Physical damage in the easternmost part of the area ranges from 30 to $80 \%$ with highest losses concentrated in the buildings close to the right boundary of the area, which has a lower elevation than the remaining site. Although this sub-area has a surface of about one third of the total study area it hosts almost half of the overall buildings because middle age constructions are denser and with smaller footprints. Flood monetary damages (panel d) are on average of the order of $380 € / \mathrm{m}^{2}$ with highest values above $1100 € / \mathrm{m}^{2}$. The overall estimated flood damage for Tr 200 years is $57.7 \mathrm{M} €$.

Panel (e) shows the correlation between the seismic physical damage and the flood physical damage. As expected, physical damages to buildings are not correlated for any period of construction. Nevertheless, two vertical clusters are notable for the XIX century buildings and the post-war buildings. They show very low flood physical damage and a larger range for the seismic one. This reflects the influence of terrain elevation in those areas that underwent reconstruction in different historical periods.

Panel (f) shows the correlation among seismic monetary damages and flood monetary damages. Although vulnerabilities and physical losses are not correlated, the use of the same market value leads to higher correlation in monetary terms. The highest correlation among monetary damages $\left(R^{2}=0.75\right)$ is found for post WWII buildings which have low vulnerability to both hazards Lower correlations are exhibited for the other periods of constructions. Namely buildings erected in the period 1860-1945 show the lower correlation $\left(R^{2}=0.41\right)$ and largest dispersion $(\mathrm{RMSE}=0.8)$ because damages are significant for the seismic scenario and quite negligible for floods.

The monetary losses for each probabilistic scenario are summarized in Table 2. Herein, current situation and the mitigated state are shown. Considering the different scenarios, the $\operatorname{Tr}$ of 500 years of the flood has been combined with the $\operatorname{Tr}$ of 475 years for the seismic risk. This particular $\operatorname{Tr}$ has been adopted in order to follow the NTC2018 seismic recommendation, where the $\operatorname{Tr}$ for a given LS is given by $\operatorname{Tr}=-(\mathrm{Vr} / \ln (1-\mathrm{Pvr}))$, where $\mathrm{Vr}$ is the Reference Life of the building and Pvr is the probability of exceeding the LS.

For the mitigated scenarios local interventions and dry floodproofing are considered to reduce seismic and flood vulnerability, respectively (Sect. 3.4). Different seismic strengthening solutions could be adopted, especially referring to cut down the monetary losses in case of high Tr. Nevertheless, the mitigations costs would increase too. For the mitigation of flood risk, the interventions are similar for each unit, i.e. backflow valves and sealing on

Table 2 Multi-hazard scenario losses in current and mitigated scenarios

\begin{tabular}{lccccc}
\hline $\begin{array}{l}\text { Return period } \\
(T r) \text { (years) }\end{array}$ & \multicolumn{2}{l}{$\begin{array}{l}\text { Monetary losses, current } \\
\text { state }(\mathrm{M} €)\end{array}$} & & \multicolumn{2}{l}{$\begin{array}{l}\text { Monetary losses, miti- } \\
\text { gated state }(\mathrm{M} €)\end{array}$} \\
\cline { 2 - 3 } \cline { 5 - 6 } \cline { 5 - 6 } & Flood & Earthquake & & Flood & Earthquake \\
\hline 10 & 0.00 & 2.75 & & 0.00 & 0 \\
30 & 0.00 & 22.99 & & 0.00 & 8.15 \\
50 & 0.00 & 37.53 & & 0.00 & 17.21 \\
72 & 0.00 & 47.89 & & 0.00 & 28.03 \\
100 & 0.73 & 55.89 & & 0.59 & 38.60 \\
200 & 57.72 & 74.47 & 39.61 & 55.00 \\
$500 / 475$ & 76.87 & 142.01 & 51.41 & 74.29 \\
\hline
\end{tabular}


basement openings. Instead, for the seismic solutions, the interventions are localized and independent unit by unit according to single-building vulnerability.

Table 2 summarizes the multi-hazard monetary losses in the current and mitigated scenarios. Flood losses have a sharp increase with the severity of the event since the study area is not affected for Tr lower than 100 years. Seismic losses have a milder increase with the severity of the event for high-medium probable events; for rare events ( $\operatorname{Tr}>200$ years), losses are much higher $\left(R_{\mathrm{C}}=1500 € / \mathrm{m}^{2}\right)$ since the damage mechanisms change, i.e.
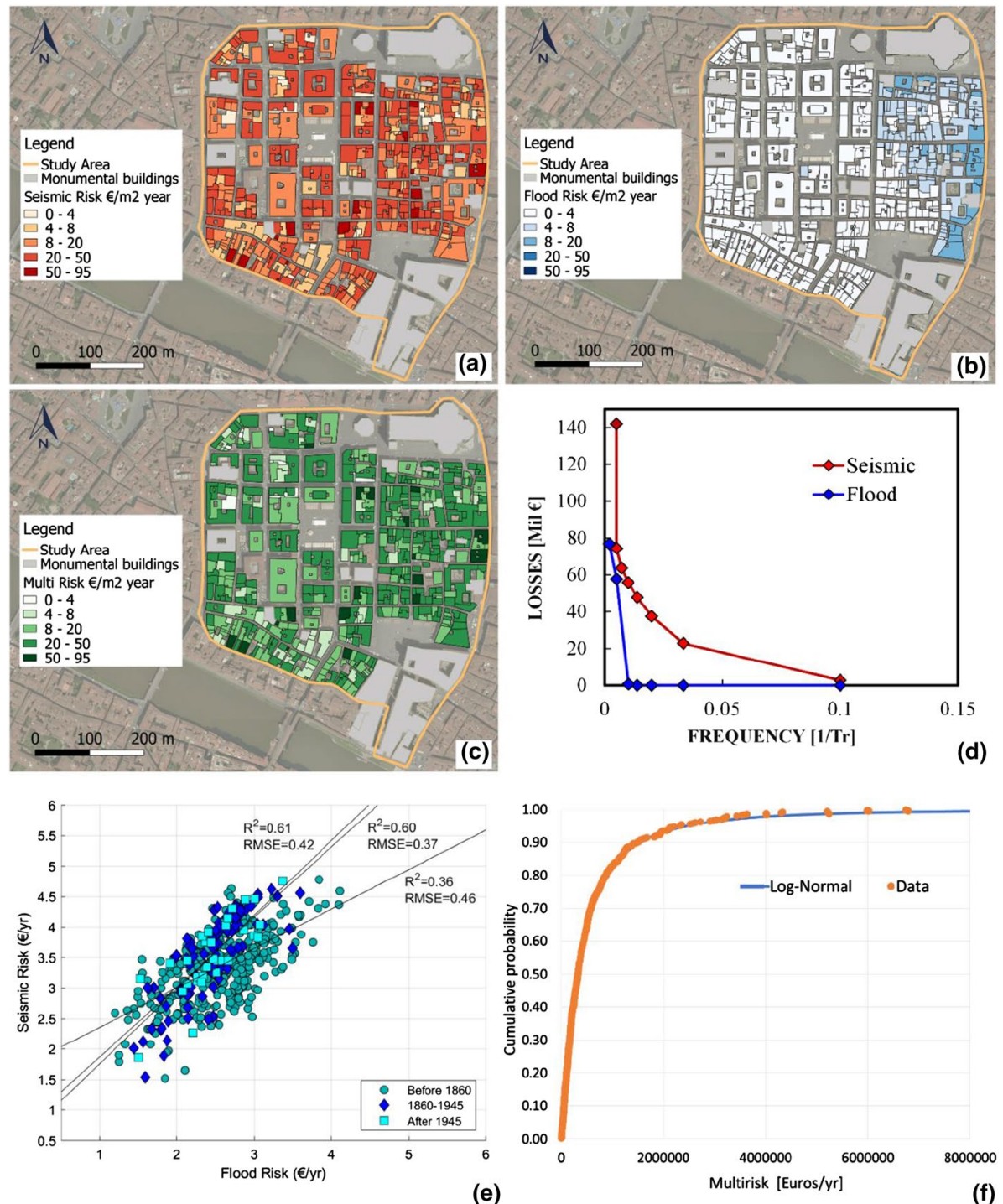

Fig. 5 Seismic risk (a), flood risk (b), multi-risk (c) damage-frequency curve (d), multi-risk correlation (Log of risk values) (e), multi-risk cumulative probability distribution (f) in the current scenario (without mitigation), (source buildings shapefile: Regione Toscana cartographic portal; background map: Bing Aerial) 
structural damages are much more expensive to recover since buildings require more than renovations.

\subsection{Multi-risk}

In this section, the multi-risk results are presented. They are firstly referred to the current and mitigated state, then considering spatial multi-risk correlation.

Concerning the current state, the single risks, and the multi-risk are shown in Fig. 5. The first two panels refer to the seismic and the flood risk, respectively, (a) and (b), while panel (c) shows the multi-risk results. Average multi-risk is $23 € / \mathrm{m}^{2}$ mostly driven by the seismic component. Higher multi-risk values are sparsely observed in the most ancient constructions, e.g. tower houses (compare Figs. 2 and 5). The overall multi-risk in the area is $3.15 \mathrm{M} € /$ year with the contribution of $2.64 \mathrm{M} € /$ year and $0.51 \mathrm{M} € /$ year of seismic and flood risk, respectively. The average seismic risk is $20.6 € / \mathrm{m}^{2}$ and the max value is $94.8 € /$ $\mathrm{m}^{2}$. Average flood risk is $3.5 € / \mathrm{m}^{2}$ with an average of $6 € / \mathrm{m}^{2}$ in the easternmost part of the area. Panel (d) shows the monetary losses for each hazard scenario (Table 2), often called damage-frequency curve used for the calculation of AAL, which highlights specific differences. The seismic risk is composed by multiple risk layers, i.e. an extensive risk layer (low Tr) a middle risk layer and an intensive risk layer (high Tr). Flood risk is placed on an intensive risk layer (no losses for low Tr, high losses for high Tr, i.e. residual risk). Figure 5 (panel (e)) shows the multi-risk correlation. Although seismic and flood hazard are uncorrelated and seismic and flood vulnerabilities are uncorrelated, the multi-risk shows a non-negligible correlation with different shapes driven by the period of construction of buildings in the historical centre. Older buildings (before 1860) exhibit a low multi-risk correlation and high dispersion $\left(R^{2}=0.36\right.$, RMSE $\left.=0.46\right)$ due to (1) large variability of geometric characteristics of the buildings (number of storey, footprint area), (2) multi-hazard vulnerability, (3) simultaneous presence of significant flood and seismic hazard. The other two groups of buildings (1860-1945 and after 1945) exhibit a higher multi-risk correlation $\left(R^{2}=0.60\right.$ and $R^{2}=0.61$, respectively) due to the dominance of seismic risk on flood risk. Multi-risk in the area follows a log-normal cumulative probability distribution (Fig. 5f) with $\mu=12.6$ and $\sigma=1.28$ (panel f).

Most of the multi-risk correlation can be explained by exposure, in fact the flood and seismic hazards are independent and physical damage is poorly correlated (Fig. 4 panel e). However, exposure is not only the monetary value adopted as recovery cost, but it also deals with the number of floors potentially affected depending on the position of the building in the study area, as shown by the exposure ratio (seismic/flood) of Fig. 3 (c). The reconstruction of the central portion of the study area around 1860 (green buildings in Fig. 2) has increased the terrain elevation, widened the roads, and substituted building materials with a consequent reduction of flood exposure and seismic vulnerability. If the unitary surface of territory is considered, multi-risk is about $16 € / \mathrm{m}^{2}$ year and $3 € / \mathrm{m}^{2}$ year for the Middle Ages and 1860-1945 districts, respectively.

The extensive seismic risk can be reduced by disaster risk reduction measures (Fig. 6, Table 2). The residual flood risk can be effectively addressed with private mitigation measures, insurance, and preparedness actions. In the hypothesis of adoption of mitigation measures, multi-risk shrinks to $1.55 \mathrm{M} €$ /year (Fig. 6). Seismic risk reduces to $1.2 \mathrm{M} € /$ year and flood risk reduces to $0.35 \mathrm{M} € /$ year. Thus, multi-risk in the area can be halved with the application of mitigation measures whose scope is the reduction of buildings vulnerability. 

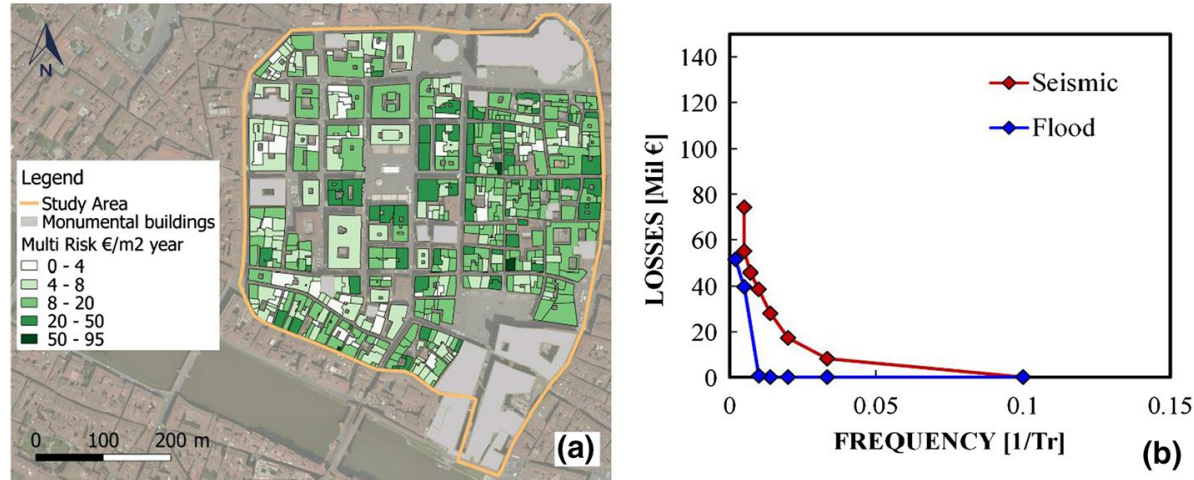

Fig. 6 Multi-risk (a) and damage-frequency curve (b) for the scenario with mitigation strategies (source buildings shapefile: Regione Toscana cartographic portal; background map: Bing Aerial)

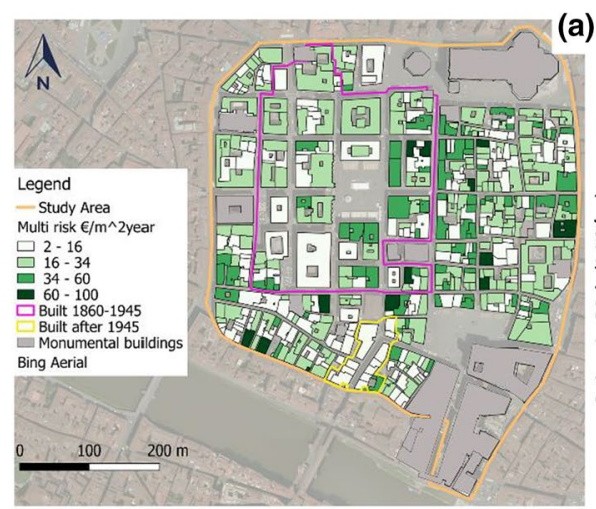

(a)

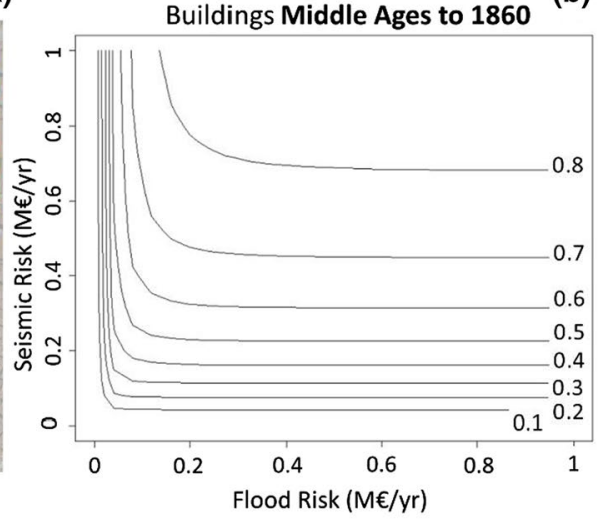

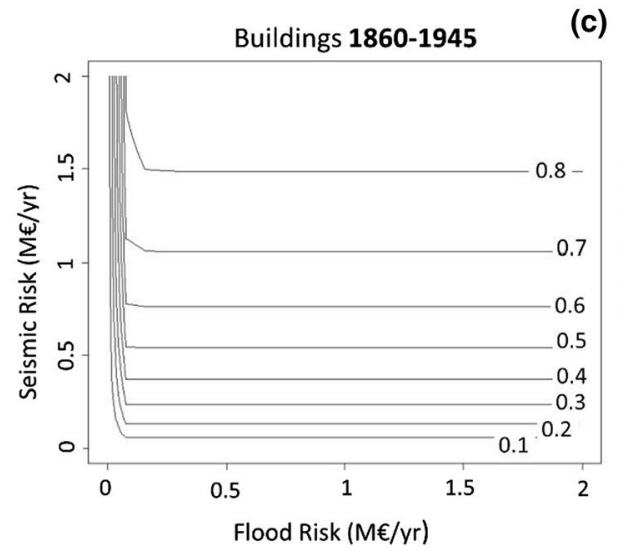

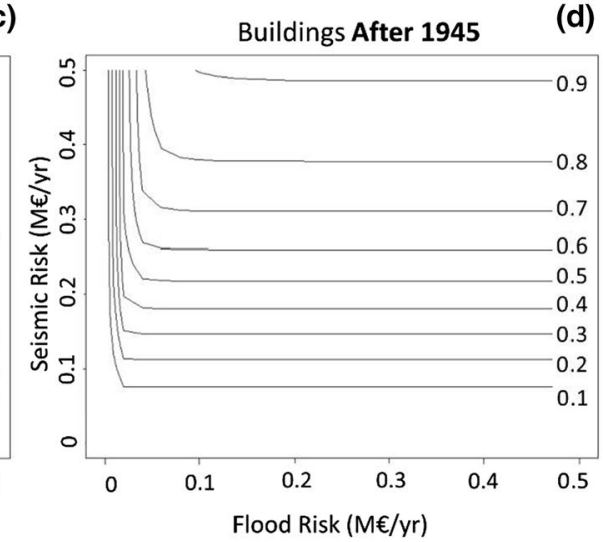

Fig. 7 Multi-risk in current state (a) (source buildings shapefile: Regione Toscana cartographic portal; background map: Bing Aerial) and joint probability contour lines for the three periods of constructions (b-d) 
The multi-risk analysis suggests that, although seismic and flood hazard are independent and vulnerabilities to the two hazards uncorrelated, a correlation between risks is present with different distinctive patterns related to the historical evolution of the city centre of Florence. This aspect is investigated by calculating multi-risk marginal and joint probability distribution in the three groups of buildings. The results of the analysis are shown in Fig. 7. In panel (a), the multi-risk map highlights that higher multi-risk values are more frequent in the older buildings. On the contrary, lower values are more frequent in the constructions built after 1945. Panels b-d show the contour joint probability curves for the three periods of construction. For the older buildings (b) which constitute the majority in the historical city centre (382 out of 495), flood risk $\left(\mathrm{AAL}_{\mathrm{f}}\right)$ and seismic risk $\left(\mathrm{AAL}_{\mathrm{s}}\right)$ both follow a log-normal marginal distribution (with parameters 10.45, 1.18; 12.32, 1.32 , respectively). The best copula for the joint distribution is a normal copula (0.61), it shows, despite the smaller footprint areas, high multi-risk values up to the order of a M€ per building and $80 \%$ values below $86 \mathrm{k} € /$ year and $670 \mathrm{k} € /$ year for flood and seismic risk, respectively.

For buildings constructed in the period 1860-1945 (c) (98 out of 495), $\mathrm{AAL}_{\mathrm{f}}$ follows a log-normal marginal distribution (with parameters 10.28, 0.96); $\mathrm{AAL}_{\mathrm{s}}$ follows a P3 marginal distribution (with parameters $3458,1,242,161,0.73$ ). $80 \%$ values are below $61.5 \mathrm{k} € /$ year and $1.5 \mathrm{M} € /$ year for flood and seismic risk, respectively. The best copula for the joint distribution is a normal copula (0.84).

For contemporary buildings (d) (15 out of 495), $\mathrm{AAL}_{\mathrm{f}}$ follows a log-normal marginal distribution (with parameters 9.85, 0.87); $\mathrm{AAL}_{\mathrm{s}}$ follows a P3 marginal distribution (with parameters $7322,118,945.7,2.09$ ). $80 \%$ values are below $40 \mathrm{k} € /$ year and $380 \mathrm{k} € /$ year for flood and seismic risk, respectively. The best copula for the joint distribution is a survival Gumbel copula.

Particularly for the period 1860-1945 (panel c) the joint cumulative probability distribution sharply lies on very high seismic risk values, because (1) low seismic vulnerability is balanced by high seismic exposure and (2) flood hazard and exposure are low (see also Fig. 3). Lower flood hazard depends on terrain elevations $0.5-1.5 \mathrm{~m}$ higher than in the XVIII century. This is a consequence of the demolition of the previous constructions, which added an artificial soil layer. It is worth noting that this elevation addition didn't aggravate the seismic hazard of the area. Indeed, the terrain elevation only regarded the superficial soil layer, while the investigated structures are placed over the underground Roman foundations (Maffei 1990).

Contemporary buildings (panel d) are characterized by the lowest multi-risk values due to very low seismic vulnerability (masonry was replaced by reinforced concrete structures) and low flood hazard.

The worst condition is found in the medieval area (a) where there is a high joint probability of having multi-risk values of the order of $0.5-1 \mathrm{M} € /$ year. This is due to the historical evolution of the area. In fact, seismic vulnerability is higher due to masonry constructions not replaced in recent times, although partly smoothed by the density of buildings which give mutual sustain to each other. The high building density, however, reduces the flood propagation to very narrow street with consequent higher water depths with respect to nearby areas. 


\section{Discussion}

The workflow introduced in this paper is targeted at assessing multi-risk of historical cities. The topic covers a gap which is justified by several issues: the complexity of multi-disciplinary subjects, the differences within the metrics associated with the different hazards as the differences involved in the methodologies (Julià and Ferreira 2021; Kappes et al. 2012a). The definition of a common path for seismic and flood hazards represents a novelty within the applications of multi-risk methods to historical cities. The analysis of spatial correlation of risk components and the adoption of joint probability distribution introduces new insights on the role of historical urban evolution in shaping multi-risk.

With respect to Grunthal et al. (2006), who also examined three different risk sources (namely storms, floods and earthquakes) in terms of AAL, this method unifies the workflow through exposure modelling instead of using three separated workflows connecting at the end of the risk estimation process. The adoption of a consistent multi-exposure model allows for directly comparing the estimated losses and AAL. Moreover, the workflow presented in this paper provides a monetary multi-risk estimation at singlebuilding level, which is more suitable for cost-benefit analysis of mitigation strategies. In fact, most of the multi-hazard works in literature adopt vulnerability indicators which provide a qualitative ranking of relative vulnerability (Julià and Ferreira 2021; Kappes et al. 2012b) or risk, which are adequate for emergency planning or identification of local priorities but not for risk management.

With respect to other works which develop frameworks for more than two hazards (Kappes et al. 2012b; Garcia-Aristizabal et al. 2015), this work does not focus on hazard interaction where hazards overlap or on cascade effects, since river floods and earthquakes are rarely observed simultaneously. The presented multi-risk workflow does not establish dependencies in vulnerability models for the different damage mechanisms caused by the two hazards. Some applications, such as the analysis of cascade hazards, e.g. earthquake and tsunami, would benefit of a deeper understanding of vulnerability interactions (Gomez-Zapata et al 2020). Nevertheless, this work examines the interaction between urban evolution and risks and provides a demonstration in the historical city centre of Florence.

Multi-risk applications in historical contexts are still scarce, so this study can arouse other works for the assessment of heritage cities. Considering the cultural heritage, multihazard vulnerability assessments were targeted at a single structure or building (Romão et al. 2016; Paupério et al. 2012; D’Ayala and et al. 2006). Historical contexts, where the urban evolution has altered the built fabric and the local terrain elevation, require a more detailed analysis of multi-risk correlations also for naturally independent hazards. The spatial joint probability analysis of multi-risk values was here considered as a valuable statistical tool to gain new knowledge about the relationship between historical urban evolution and natural hazards, which could support the identification and prioritization of mitigation interventions.

The results denounce a non-negligible correlation in terms of multi-exposure and multirisk as shown in the scatter plots of Figs. 3, 4, 5. This is mostly driven by the different building types and built density of the sub-areas composing the city centre, i.e. the medieval, modern, and contemporary ones, which point out the role of the urban evolution in shaping multi-hazard and multi-vulnerabilities. The outcomes show how, the more the urban cluster are historically identifiable and categorizable, the more they tend to influence the multi-risk response at urban scale. 
Considering the two risks, despite the multi-risk positioning of this research, intrinsic differences are involved. They deal with the different peculiarities influencing the two hazards and vulnerabilities, which cannot mutually interfere, such as the portions of the building potentially harmed by earthquakes and floods and the different behaviours of the construction materials under the hazard action. Nonetheless, the outcomes of this work point out common aspects concerning the spatial evolution of the city. The urban layout alterations reciprocally affect the two risks, as highlighted by multi-risk spatial clustering. In fact, in the study area, the medieval part is the most vulnerable to both hazards.

The sources of multi-hazard information used in this work could be further improved if high resolution 2D hydraulic models or seismic micro-zonations were available, however the presented workflow maintains its validity also if different hazard, exposure or vulnerability models are adopted, provided that consistency in the spatial resolution and exposure are ensured.

Obviously, the adopted exposure and vulnerability assumptions cannot be transferred to monumental buildings, which might constitute a non-negligible fraction of structures in historical city centres. Monumental buildings are usually examined by means of structural modelling for seismic vulnerability, while flood vulnerability is rarely investigated with such a detailed scale.

A sensitivity analysis is crucial to understand the relative importance of variables and parameters (see for instance Arrighi et al. 2018; Shahri et al. 2019; Lagomarsino et al., 2021). The most sensitive parameter in the proposed multi-risk workflow is the value of exposure, whose variations affect the estimated losses with an elastic behaviour, i.e. $1 \%$ variation of exposed monetary value generates $1 \%$ variation of the estimated loss. Moreover, although modelled multi-hazard losses are affected by epistemic uncertainty, that could be further investigated, the selected vulnerability models provide monetary losses which are pretty like those observed in recent flood and seismic event in Italy (Molinari et al. 2020; Scorzini and Frank 2015; Dolce and Manfredi 2015), thus they can be considered an acceptable estimation. The availability of loss data for the study area would significantly help in validating the adopted vulnerability models and in reducing uncertainties (Ahmad et al. 2014), however data of the 1966 flood and 1895 earthquake are not available.

The workflow has been proposed for flood and earthquake hazards, nonetheless, it can be easily extended to include further risks. The framework has been conceived based on the geographic and socio-economic data sources usually available, so considering only the direct losses. Further studies could improve the methodology through the computation of indirect losses and intangible losses which are crucial when outstanding cultural, aesthetic and spiritual values are affected.

\section{Conclusions}

This work introduced a multi-risk workflow for site-scale applications in historical contexts, which encompassed hazard, exposure, vulnerability, and spatial correlation analyses. Peak Ground Acceleration and flood depths were the representative hazard intensity measures for earthquakes and floods, respectively. Exposure was modelled by using the same unifying GIS buildings layer where all storeys or basement plus ground floor were considered for earthquakes and floods, respectively. Recovery costs were referred to building renovation except for those earthquakes with high intensity where significant reconstruction works are expected. The consistency in exposure modelling allowed for a direct 
combination of risks in a multi-risk AAL, which overcomes the gaps of studies suffering from a difficult identification of common metrics to properly compare potential damages (De Ruiter et al. 2017). Comparable monetary estimations of AAL allows for a more quantitative cost-benefit analysis of the possible mitigation interventions. Moreover, given the complexity of urban texture in historical cities, the work introduced the spatial joint probability analysis to identify multi-risk correlations and the role of historical evolution in shaping current multi-risk.

The method was applied to the historical city centre of Florence (Italy). In the current situation, multi-risk equals $3.15 \mathrm{M} €$ /year. However, with limited local mitigation measures such as waterproofing of basements and local reinforcements with tie rods, multi-risk can be reduced to $1.55 \mathrm{M} € / \mathrm{yr}$.

The marginal and joint probability analysis highlighted that the historical evolution of the city centre led to a spatial separation of three sub-areas characterized by different multi-risk values: the most at risk (1) middle-age and renaissance area where flood hazard is aggravated by high building density and seismic vulnerability is higher due to construction materials and building height; (2) the average risk central area with modern buildings constructed upon older existing foundations and larger roads which, on one hand, reduce flood hazard and on the other, show lower seismic vulnerabilities; (3) the post WWII area with few RC buildings with the lowest multi-risk values. Thus, although seismic and flood hazards with respective vulnerabilities are independent and uncorrelated, multi-risk shows a non-negligible correlation with distinctive behaviours due to the historical development of the historical city centre.

Further research could deepen the multi-risk workflow to account for dependent natural hazards, such as landslides triggered by earthquakes. Then, the workflow could be extended to assess multi-hazard indirect impacts related to economic activities and/or nonmonetary impact metrics to understand the social value of cultural heritage losses.

Supplementary Information The online version contains supplementary material available at https://doi. org/10.1007/s11069-021-05125-6.

Author contributions CA was responsible for flood risk modelling, statistical analysis of results and mapping. She also contributed to the definition of multi-risk methodology. MT, and MTC were responsible for seismic risk modelling and contribute to the definition of the multi-risk methodology. VC and AM supported the revision of literature. MS and FC supervised and revised the work. Manuscript writing and revision, all authors.

Funding This work was supported by the Italian Ministry of Education, University and Research within the PRIN funding programme 2015 WELAX9, project MICHe.

Data availability The hazard and GIS data are open access data whose source is shown in Table 1. The results are available at this link. https://drive.google.com/drive/folders/1o8oQ8ay-dONFQk1t4id4aTV 8pWGQ3rAc?usp=sharing.

\section{Declarations}

Conflict of interest Authors do not have conflicts of interest to declare.

Open Access This article is licensed under a Creative Commons Attribution 4.0 International License, which permits use, sharing, adaptation, distribution and reproduction in any medium or format, as long as you give appropriate credit to the original author(s) and the source, provide a link to the Creative Commons licence, and indicate if changes were made. The images or other third party material in this article are included in the article's Creative Commons licence, unless indicated otherwise in a credit line to the material. If material is not included in the article's Creative Commons licence and your intended use is not 
permitted by statutory regulation or exceeds the permitted use, you will need to obtain permission directly from the copyright holder. To view a copy of this licence, visit http://creativecommons.org/licenses/by/4.0/.

\section{References}

Agenzia delle Entrate OMI (2020) Osservatorio Mercato Immobiliare. https://wwwt.agenziaentrate.gov.it/ geopoi_omi/index.php. Accessed 27 Oct (in Italian)

Ahmad N, Ali Q, Crowley H et al (2014) Earthquake loss estimation of residential buildings in Pakistan. Nat Hazards 73:1889-1955. https://doi.org/10.1007/s11069-014-1174-8

Aksha SK, Resler LM, Juran L, Carstensen LW (2020) A geospatial analysis of multi-hazard risk in Dharan, Nepal. Geoma Nat Hazards Risk 11(1):88-111. https://doi.org/10.1080/19475705.2019.1710580

Annis A, Nardi F, Petroselli A, Apollonio C, Arcangeletti E, Tauro F, Belli C, Bianconi R, Grimaldi S (2020) UAV-DEMs for small-scale flood hazard mapping. Water 12:1717. https://doi.org/10.3390/ w12061717

Appiotti F, Assumma V, Bottero M, Campostrini P, Datola G, Lombardi P, Rinaldi E (2020) Definition of a risk assessment model within a european interoperable database platform (EID) for cultural heritage. J Cult Herit 46:268-277. https://doi.org/10.1016/j.culher.2020.08.001

Araya-Muñoz D, Metzger MJ, Stuart N, Wilson AMW, Carvajal D (2017) A spatial fuzzy logic approach to urban multi-hazard impact assessment in Concepción, Chile. Sci Total Environ 576:508-519. https:// doi.org/10.1016/j.scitotenv.2016.10.077

Arrighi C, Brugioni M, Castelli F, Franceschini S, Mazzanti B (2018) Flood risk assessment in art cities: the exemplary case of Florence (Italy). J Flood Risk Manag. https://doi.org/10.1111/jfr3.12226

Arrighi C, Brugioni M, Castelli F, Franceschini S, Mazzanti B (2013) Urban micro-scale flood risk estimation with parsimonious hydraulic modelling and census data. Nat Hazards Earth Syst Sci 13:13751391. https://doi.org/10.5194/nhess-13-1375-2013

Autorità di Bacino Distrettuale dell'Appennino Settentrionale (2018) Piano di Gestione del Rischio Alluvioni [online] available at http://www.appenninosettentrionale.it/itc/?page_id=55. Last access 22 Oct 2020 , (in Italian)

Arrighi C, Campo L (2019) Effects of digital terrain model uncertainties on high-resolution urban flood damage assessment. J Flood Risk Manag 12:1-12. https://doi.org/10.1111/jfr3.12530

Bernardini A (2000) Attività del Gruppo di Lavoro GNDT-SSN per I rilievi di danno/vulnerabilità sismica degli edifici. In: La vulnerabilità degli edifici. Valutazione a scala nazionale della vulnerabilità sismica degli edifici ordinari, CNR-GNDT, Roma, pp. 11-31, (in Italian)

Bernardini G, Ferreira TM (2020) Simulating to evaluate, manage and improve earthquake resilience in historical city centers: application to an emergency simulation-based method to the historic centre of Coimbra. ISPRS Int Arch Photogramm Remote Sens Spatial Inf Sci. https://doi.org/10.5194/ isprs-archives-xliv-m-1-2020-651-2020

Blyth A, Di Napoli B, Parisse F et al (2020) Assessment and mitigation of seismic risk at the urban scale: an application to the historic city center of Leiria, Portugal. Bull Earthquake Eng 18:2607-2634. https:// doi.org/10.1007/s10518-020-00795-2

Caprili S, Mangini F, Paci S, Salvatore W, Bevilacqua MG, Karwacka E, Iannelli P (2017) A knowledgebased approach for the structural assessment of cultural heritage, a case study: La Sapienza Palace in Pisa. Bull Earthq Eng 15(11):4851-4886. https://doi.org/10.1007/s10518-017-0158-y

Cara S, Aprile A, Pelà L, Roca P (2018) Seismic risk assessment and mitigation at emergency limit condition of historical buildings along strategic urban roadways: application to the "Antiga Esquerra de L'Eixample" Neighborhood of Barcelona. Int J Arch Heritage 12(78):1055-1075. https://doi.org/10. 1080/15583058.2018.1503376

Cardinali V, Cristofaro MT, Ferrini M, Nudo R, Paoletti B, Tanganelli M (2020) An Interdisciplinary approach for the seismic vulnerability assessment of historical centres in masonry building aggregates: application to the city of Scarperia, Italy. ISPRS Int Arch Photogramm Remote Sens Spatial Inf Sci.https://doi.org/10.5194/isprs-archives-xliv-m-1-2020-667-2020

Carisi F, Schröter K, Domeneghetti A, Kreibich H, Castellarin A (2018) Development and assessment of uni- and multivariable flood loss models for Emilia-Romagna (Italy). Nat Hazards Earth Syst Sci 18:2057-2079. https://doi.org/10.5194/nhess-18-2057-2018

Carpignano A, Golia E, Di Mauro C, Bouchon S, Nordvik JP (2009) A methodological approach for the definition of multi-risk maps at regional level: first application. J. Risk Res 12(3e4):513-534. https:// doi.org/10.1080/13669870903050269 
Catulo R, Falcão AP, Bento R, Ildefonso S (2018) Simplified evaluation of seismic vulnerability of Lisbon Heritage City Centre based on a 3DGIS-based methodology. J Cult Herit. https://doi.org/10.1016/j. culher.2017.11.014

Cavaleri L, Di Trapani F, Ferrotto MF (2017) A new hybrid procedure for the definition of seismic vulnerability in Mediterranean cross-border urban areas. Nat Hazards. https://doi.org/10.1007/ s11069-016-2646-9

Centre for Ecology \& Hydrology (1999) Flood estimation handbook. ISBN:9781906698003

Chieffo N, Formisano A, Miguel Ferreira T (2019) Damage scenario-based approach and retrofitting strategies for seismic risk mitigation: an application to the historical Centre of Sant'Antimo (Italy). Eur J Environ Civ Eng. https://doi.org/10.1080/19648189.2019.1596164

Ciurean RL, Schroeter D, Glade T (2013) Conceptual frameworks of vulnerability assessments for natural disasters reduction. In: Tiefenbacher, J. (Ed.), Approaches to disaster management: examining the Implications of Hazards, Emergencies and Disasters, InTech, pp. 3-32. https://doi.org/10.5772/55538

Cosenza E, Del Vecchio C, Di Ludovico M, Dolce M, Moroni C, Prota A, Renzi E (2018) The Italian guidelines for seismic risk classification of constructions: technical principles and validation. Bull Earthq Eng 16:5905-5935. https://doi.org/10.1007/s10518-018-0431-8

D’Agostino G, Di Pietro A, Giovinazzi A, La Porta L, Pollino M, Rosato V, Tofani A (2019) Earthquake simulation on urban areas: improving contingency plans by damage assessment. In: Luiijf E., Žutautaitė I., Hämmerli B. (eds) Critical information infrastructures security, CRITIS 2018, Lecture Notes in Computer Science, vol 11260, Springer, Cham

D’Ayala D, Spence R, Oliveira C, Pominos A (1997) Earthquake loss estimation for Europe's historic town centres. Earthq Spectra 13(4):773-793. https://doi.org/10.1193/1.1585980

D’Ayala D, Copping A, Wang H (2006) A conceptual model for multi-hazard assessment of the vulnerability of historic buildings. In: Lourenco PB, Roca P, Modena C, Agrawal S (Eds.) Structural analysis of historical constructions: possibilities of numerical and experimental techniques. In: Proceedings of the fifth international conference (pp. 121-140). New Delhi, India

Deierlein GG, Zsarnóczay A (2021) State of the Art in Computational Simulation for Natural Hazards Engineering, Sim Center Report No. 2021-01 https://doi.org/10.5281/zenodo.2579581, 2nd edition

Despotaki V, Silva V, Lagomarsino S, Pavlova I, Torres J (2018) Evaluation of seismic risk on UNESCO cultural heritage sites in Europe. Int J Arch Heritage. https://doi.org/10.1080/15583058.2018.15033 74

De Ruiter MC, Ward PJ, Daniell JE, Aerts JCJH (2017) Review Article: a comparison of flood and earthquake vulnerability assessment indicators. Nat Hazard 17:1231-1251. https://doi.org/10.5194/ nhess-17-1231-2017

De Stefano M, Cristofaro MT (2020) The Complex of the Galleria dell'Accademia of Florence: keeping in safety, Art Collections 2020, Safety Issue (ARCO 2020, SAFETY). Procedia Struct Integrity 29(2020):71-78. https://doi.org/10.1016/j.prostr.2020.11.141

Directive 2007/60/EC of the European Parliament and of the Council of 23 October 2007 on the assessment and management of flood risks (Text with EEA relevance) OJ L 288, 06/11/2007, p. 27-34

Dolce M, Manfredi G (2015) Libro bianco sulla ricostruzione privata fuori dai centri storici nei comuni colpiti dal sisma dell'Abruzzo del 6 Aprile 2009 (in Italian)

Dottori F, Szewczyck W, Ciscar JC, Zhao F, Alfieri L, Hirabayashi Y, Bianchi A, Mongelli I, Frieler K, Betts RA, Feyen L (2018) Increased human and economic losses from river flooding with anthropogenic warming. Nat Clim Chang 8(781-786):1758-2678

Dottori F, Kalas M, Salamon P, Bianchi A, Alfieri L, Feyen L (2017) An operational procedure for rapid flood risk assessment in Europe. Nat Hazard 17(7):1111-1126. https://doi.org/10.5194/ nhess-17-1111-2017

EN 1998-1 (English) (2004) Eurocode 8: Design of structures for earthquake resistance - Part 1: General rules, seismic actions and rules for buildings

Fatoric S, Seekamp E (2017) Securing the future of cultural heritage by identifying barriers to and strategizing solutions for preservation under changing climate conditions. Sustainability 9(11):2143. https://doi.org/10.3390/su9112143

Federal Emergency Management Agency (2000) FEMA-356: Prestandard and Commentary for Seismic Rehabilitation of Buildings, Washington DC

Ferreira TM, Maio R, Vicente R (2016) Seismic vulnerability assessment of the old city centre of Horta, Azores: calibration and application of a seismic vulnerability index method. Bull Earthq Eng 15(7):2879-2899. https://doi.org/10.1007/s10518-016-0071-9

Ferreira TM, Vicente R, Mendes Silva JAR, Varum H, Costa A (2013) Seismic vulnerability assessment of historical urban centres: case study of the old city centre in Seixal, Portugal. Bull Earthq Eng 11:1753-73. https://doi.org/10.1007/s10518-013-9447-2 
Ferreira TM, Romão X, Lourenço PB, Paupério E, Martins N (2020) Risk and resilience in practice: cultural heritage buildings. Int J Arch Heritage. https://doi.org/10.1080/15583058.2020.1759007

Figueiredo R, Romão X, Paupério E (2019) Flood risk assessment of cultural heritage at large spatial scales: framework and application to mainland Portugal. J Cult Herit. https://doi.org/10.1016/j. culher.2019.11.007

Galasso C, Pregnolato M, Parisi F (2021) A model taxonomy for flood fragility and vulnerability assessment of buildings. Int J Disaster Risk Reduction. https://doi.org/10.1016/j.ijdrr.2020.101985

Gallina V, Torresan S, Critto A, Sperotto A, Glade T, Marcomini A (2016) A review of multi-risk methodologies for natural hazards: consequences and challenges for a climate change impact assessment. J Environ Manag 168:123-132. https://doi.org/10.1016/j.jenvman.2015.11.011

Gallina V, Torresan S, Zabeo A, Critto A, Glade T, Marcomini A (2020) A multi-risk methodology for the assessment of climate change impacts in coastal zones. Sustainability. https://doi.org/10.3390/ su12093697

Galloway GE, Seminara G, Blöschl G, García MH, Montanari A, Solari L (2020) Reducing the flood risk of art cities: the case of florence. J Hydraul Eng 146:1-7. https://doi.org/10.1061/(ASCE)HY. 1943-7900.0001741

Galloway G, Seminara G, Blöschl G, Garcia M, Montanari A, Solari L (2017) Saving a world treasure: protecting florence from flooding, ISBN 8864536779

Garcia-Aristizabal A, Marzocchi W (2011) State-of-the-art in Multi-risk Assessment, Deliverable 5.1. MATRIX project (Contract n 265138) Available online: https://cordis.europa.eu/project/rcn/ 96701/reporting/en

Garcia-Aristizabal A, Gasparini P, Uhigna G (2015) Multi-risk assessment as a tool for decision-making. In: Pauleit $\mathrm{S}$ et al (eds) Urban vulnerability and climate change in Africa. Springer, Cham

Gardoni P, LaFave JM (2016) Multi-hazard approaches to civil infrastructure engineering: mitigating risks and promoting resilience, Springer International Publishing. Switzerland. https://doi.org/10. 1007/978-3-319-29713-2

Garrote J, Diez-Herrero A, Escudero C, Garcia I (2019) Upon specific ultra-detailed stage-damage functions A proposed framework for flood risk assessment in cultural heritage sites upon specific ultradetailed stage-damage functions, Conference: 11th World Congress on Water Resources and Environment (EWRA 2019)At: Madrid (Spain)

Garrote J, Diez-Herrero A, Escudero C, Garcia I (2020) A framework proposal for regional-scale flood-risk assessment of cultural heritage sites and application to the castile and león region. Water 12:329. https://doi.org/10.3390/w12020329

Geiß C, Thoma M, Pittore M, Wieland M, Dech S, Taubenböck H (2017) Multitask active learning for characterization of built environments with multisensor earth observation data. IEEE J Sel Top Appl Earth Observ Remote Sens 10(12):5583-5597

Gill JC, Malamud BD (2014) Reviewing and visualizing the interactions of natural hazards. Rev Geophys 52:680-722. https://doi.org/10.1002/2013RG000445

Giovinazzi S, Lagomarsino S (2004) A macroseismic model for the vulnerability assessment of buildings. In: 13th World conference on earthquake engineering, Vancouver, Canada

Girgin S, Necci A, Krausmann E (2019) Dealing with cascading multi-hazard risks in national risk assessment: the case of Natech accidents. Int J Disast Risk Reduct 35:101072

Goda K, De Risi R (2018) Multi-hazard loss estimation for shaking and tsunami using stochastic rupture sources. Int J Disaster Risk Reduct 28:539-554. https://doi.org/10.1016/j.ijdrr.2018.01.002

Gomez-Zapata JC, Pittore M, Brinckmann N, Shinde S (2020) Dynamic physical vulnerability: a Multi-risk Scenario approach from building- single- hazard fragility- models, EGU General Assembly 2020, Online, 4-8 May 2020, EGU2020-18379, https://doi.org/10.5194/egusphere-egu2020-18379

Granda S, Ferreira TM (2019) Assessing vulnerability and fire risk in old urban areas: application to the Historical Centre of Guimarães. Fire Technol. https://doi.org/10.1007/s10694-018-0778-z

Grünthal G (1998) European Macroseismic Scale 1998 (EMS-98), Cahiers du Centre Européen de Géodynamique et de Séismologie 15, In Centre Européen de Géodynamique et de Séismologie, Luxembourg

Grünthal G, Thieken AH, Schwarz J, Radtke KS, Smolka A, Merz B (2006) Comparative risk assessments for the city of Cologne, Germany: storms, floods, earthquakes. Nat Hazards 38(1-2):21-44

Guidoboni E (2018) Florence: the effects of earthquakes on the artistic heritage. Method and historical sources (15th-20th), VII Convegno di Storia dell'Ingegneria. In: 3rd International conference proceedings, Napoli. International Journal for Housing Science and Its Applications. 37(4): 229-238

Hassanzadeh R, Nedović- Budić Z, Alavi Razavi A, Norouzzadeh M, Hodhodkian H (2013) Interactive approach for GIS-based earthquake scenario development and resource estimation (Karmania hazard model). Comput Geosci. https://doi.org/10.1016/j.cageo.2012.08.016 
Hofert M, Kojadinovic I, Maechler M, Yan J, Nešlehová JG, Morger R (2020) Package 'copula', [available online at https://cran.r-project.org/web/packages/copula/copula.pdf. last access 2-5-21

Hufschmidt G, Glade T (2010) Vulnerability analysis in geomorphic risk assessment. In: Alcantara-Ayala I, Goudie AS (eds) Geomorphological Hazards and Disaster Prevention. Cambridge University Press, pp 233-243

ISTAT (2011) Censimento della popolazione e delle abitazioni, public dataset. Available at https://www. istat.it/it/censimenti-permanenti/censimenti-precedenti/popolazione-e-abitazioni/popolazione-2011

Julià PB, Ferreira TM (2021) From single- to multi-hazard vulnerability and risk in Historic Urban Areas: a literature review. Nat Hazards 108:93-128. https://doi.org/10.1007/s11069-021-04734-5

Kappes M, Keiler M, Glade T (2010) From single- to multi-hazard risk analyses: a concept addressing emerging challenges. In: Malet JP, Glade T, Casagli N (Eds.), Mountain risks: bringing science to society, Proceedings of the International Conference, Florence, CERG Editions, Strasbourg, pp. 351-356

Kappes MS, Keiler M, von Elverfeldt K, Glade T (2012) a) Challenges of analyzing multi-hazard risk: a review. Nat Hazards 64(2):1925-1958. https://doi.org/10.1007/s11069-012-0294-2

Kappes MS, Papathoma-Köhle M, Keiler M (2012) Assessing physical vulnerability for multi-hazards using an indicator-based methodology. Appl Geogr 32:577-590. https://doi.org/10.1016/j.apgeog.2011.07. 002

Karimzadeh S, Miyajima M, Hassanzadeh R, Amiraslanzadeh R, Kamel B (2014) A GIS-based seismic hazard, building vulnerability and human loss assessment for the earthquake scenario in Tabriz. Soil Dyn Earthq Eng. https://doi.org/10.1016/j.soildyn.2014.06.026

Koks EE, Rozenberg J, Zorn C et al (2019) A global multi-hazard risk analysis of road and railway infrastructure assets. Nat Commun 10:2677. https://doi.org/10.1038/s41467-019-10442-3

Komendantova N, Mrzyglocki R, Mignan A, Khazai B, Wenzel F, Patt A, Fleming K (2014) International Journal of Disaster Risk Reduction Multi-hazard and multi-risk decision-support tools as a part of participatory risk governance: feedback from civil protection stakeholders. Int J Disaster Risk Reduct 8:50-67. https://doi.org/10.1016/j.ijdrr.2013.12.006

Kumar P (2020) Crowdsourcing to rescue cultural heritage during disasters: a case study of the 1966 Florence Flood. Int J Disaster Risk Reduct 43:101371. https://doi.org/10.1016/j.ijdrr.2019.101371

Lacanna G, Deguy P, Ripepe M, Coli M, Paoletti B, Barducci S, Tanganelli M, Viti S, De Stefano M (2016) Seismic hazard of urban areas: a case study, In: ECCOMAS Congress 2016 - VII European Congress on Computational Methods in Applied Sciences and Engineering, Crete Island, Greece, 5-10, June, DOI: https://doi.org/10.7712/100016.2232.10806

Lagomarsino S (2006) On the vulnerability assessment of monumental buildings. Bull Earthq Eng 4(4):445-463. https://doi.org/10.1007/s10518-006-9025-y

Lagomarsino S, Cattari S, Ottonelli D (2021) The heuristic vulnerability model: fragility curves for masonry buildings. Bull Earthq Eng 19:3129-3163. https://doi.org/10.1007/s10518-021-01063-7

Lagomarsino S, Giovinazzi S (2006) Macroseismic and mechanical models for the vulnerability assessment of current buildings. Bull Earthq Eng 4(4):445-463. https://doi.org/10.1007/ s10518-006-9024-z

Lantada N, Irizarry J, Barbat AH, Goula X, Roca A, Susagna T, Pujades LG (2010) Seismic hazard and risk scenarios for Barcelona, Spain, using the Risk-UE vulnerability index method. Bull Earthq Eng 8(2):201-229. https://doi.org/10.1007/s10518-009-9148-z

Laudan J, Rözer V, Sieg T, Vogel K, Thieken AH (2017) Damage assessment in Braunsbach 2016: data collection and analysis for an improved understanding of damaging processes during flash floods. Nat Hazards Earth Syst Sci 17:2163-2179. https://doi.org/10.5194/nhess-17-2163-2017

Liu J, Xu Z, Chen F, Chen F, Zhang L (2019) Flood hazard mapping and assessment on the angkor world heritage site Cambodia. Remote Sens. https://doi.org/10.3390/rs11010098

Losacco U (1967) Notizie e considerazioni sulle inondazioni d'Arno in Firenze. L'Universo 5:720, (in Italian)

Maffei GL (1990) La casa fiorentina nella storia della città. Dalle origini all'Ottocento, Marsilio, (in Italian)

Maio R, Vicente R, Formisano A, Varum H (2015) Seismic vulnerability of building aggregates through hybrid and indirect assessment techniques. Bull Earthq Eng 13(10):2995-3014. https://doi.org/10. 1007/s10518-015-9747-9

Margottini C, Molin D, Serva L (1992) Intensity versus ground motion: a new approach using Italian data. Eng Geol. https://doi.org/10.1016/0013-7952(92)90034-V

Marzocchi W, Garcia-Aristizabal A, Gasparini P, Mastellone ML, Di Ruocco A (2012) Basic principles of multi-risk assessment: a case study in Italy. Nat Hazards 62:551-573. https://doi.org/10.1007/ s11069-012-0092-x 
Matassoni L, Giovinazzi S, Pollino M, Fiaschi A, La Porta L, Rosato V (2017) A geospatial decision support tool for seismic risk management: florence (Italy) case study. Lecture Notes Comput Sci. https://doi.org/10.1007/978-3-319-62395-5_20

Merz B, Kreibich H, Schwarze R, Thieken A (2010) Review article "assessment of economic flood damage.” Nat Hazards Earth Syst Sci 10:1697-1724. https://doi.org/10.5194/nhess-10-1697-2010

Milosevic JI, Bento R, Cattari S (2020) 3DGIS representation for supporting seismic mitigation policies at urban scale: the case study of Lisbon. J Cult Herit. https://doi.org/10.1016/j.culher.2020.04.001

Miranda FN, Ferreira TM (2019) A simplified approach for flood vulnerability assessment of historic sites. Nat Hazards. https://doi.org/10.1007/s11069-018-03565-1

MIT (2017) Decreto del Ministro delle Infrastrutture e dei Trasporti n 58 del 28/02/2017. Allegato A: Linee guida per la classificazione del rischio sismico delle costruzioni, Rome, Italy, (in Italian)

Molin D, Paciello A (1999) Seismic hazard assessment in Florence city Italy. J Earthquake Eng 3(4):475-494. https://doi.org/10.1080/13632469909350356

Molinari D, Scorzini AR, Arrighi C, Carisi F, Castelli F, Domeneghetti A, Gallazzi A, Galliani M, Grelot F, Kellermann P, Kreibich HGM, Moimann M, Natho S, Richert C, Schroeter K, Thieken A, Zischg AP, Ballio F (2020) Are flood damage models converging to "reality"? Lessons learnt from a blind test. Nat Hazards Earth Syst Sci 20:2997-3017. https://doi.org/10.5194/nhess-20-2997-2020

Munich Re: The 2019 natural catastrophe year at a glance. [Online] https://www.munichre.com/en/ company/media-relations/media-information-and-corporate-news/media-information/2020/causi ng-billions-in-losses-dominate-nat-cat-picture-2019.html Last access 10-12-20, 2020

Napolitano RK, Hess M, Glisic B (2019) The foundation walls of the Baptistery Di San Giovanni: a combination of laser scanning and finite-distinct element modeling to ascertain damage origins. Int J Arch Heritage 13:1180-1193. https://doi.org/10.1080/15583058.2019.1582726

Nencini F (1966) Firenze i giorni del diluvio, Editore Sansoni, (in Italian)

Notaro V, De Marchis M, Fontanazza CM, La Loggia G, Puleo V, Freni G (2014) The effect of damage functions on urban flood damage appraisal. Proc Eng. https://doi.org/10.1016/j.proeng.2014.02.138

NTC (2018) Aggiornamento delle «Norme tecniche per le costruzioni». G.U. No. 42 del 20 Febbraio D.M. Ministero Infrastrutture e Trasporti 17 gennaio 2018, Roma (in Italian)

Papilloud T, Röthlisberger V, Loreti S, Keiler M (2020) Flood exposure analysis of road infrastructure: comparison of different methods at national level. Int J Disaster Risk Reduct. https://doi.org/10. 1016/j.ijdrr.2020.101548

Paupério E, Romão X, Costa A (2012) A methodology for the vulnerability assessment of heritage buildings and contents under catastrophic hazard. ICOMOS-ICORP. In: International symposium on cultural heritage protection in times of risk: challenges and opportunities, Istanbul, Turkey

Pegna ML (1974) Firenze dalle origini al Medioevo, Firenze, Del Re Editore (in Italian)

Porebska A, Radzicki K, Rizzi P (2019) Built heritage, sustainable development, and natural hazards: Flood protection and UNESCO world heritage site protection strategies in Krakow. Poland. https://doi.org/ $10.3390 / \mathrm{su} 11184886$

Pourghasemi HR, Gayen A, Edalat M, Zarafshar M, Tiefenbacher JP (2020) Is multi-hazard mapping effective in assessing natural hazards and integrated watershed management? Geosci Front 11:4. https:// doi.org/10.1016/j.gsf.2019.10.008

QGIS Geographic Information System 2.18.24. Open Source Geospatial Foundation Project. http://qgis. osgeo.org

Rahmati O, Yousefi S, Kalantari Z, Uuemaa E, Teimurian T, Keesstra S, Pham TD, Bui DT (2019) Multihazard exposure mapping using machine learning techniques: a case study from Iran. Remote Sens 11:1-20. https://doi.org/10.3390/rs11161943

Reimann L, Vafeidis A, Brown S, Hinkel J, Tol RSJ (2018) Mediterranean UNESCO world heritage at risk rise. Nat Commun 9:4161. https://doi.org/10.1038/s41467-018-06645-9

Ripepe M, Lacanna G, Deguy P, De Stefano M, Mariani V, Tanganelli M (2015) Large-scale seismic vulnerability assessment method for urban centres. An application to the city of Florence. Eng Mater 628:49-54. https://doi.org/10.4028/www.scientific.net/KEM.628.49

Ripepe M, Lacanna G, Deguy P, Cristofaro MT, De Stefano M, Tanganelli M, Paoletti B, Cardinali V, Viti S, Bertaccini B, Rocco E, Giommi A (2018.) Rischio sismico di aree urbane complesse: progetto Sismed, In: ReUSO 2018: VI Convegno Internazionale sulla documentazione, conservazione e recupero del patri-monio architettonico e sulla tutela paesaggistica, Messina, 11-13 ottobre 2018, Gangemi Editore spa, pp. 903-910, ISBN:9788849236590 (in Italian)

Romão X, Paupério E, Pereira N (2016) A framework for the simplified risk analysis of cultural heritage assets. J Cult Herit 20:696-708. https://doi.org/10.1016/j.culher.2016.05.007

Rovida A, Locati M, Camassi R, Lolli B, Gasperini P (2016) Catalogo Parametrico dei Terremoti Italiani, release 2015, INGV., https://emidius.mi.ingv.it/CPTI15-DBMI15/description_CPTI15.htm

Saidi S, Ghattassi A, Anselme B, Bouri S (2019) GIS based multi-criteria analysis for flood risk assessment: case of Manouba Essijoumi Basin. NE Tunisia. https://doi.org/10.1007/978-3-030-01440-7_64 
Salvadori G, De Michele C (2004) Frequency analysis via copulas: theoretical aspects and applications to hydrological events. Water Resour Res 40:1-17. https://doi.org/10.1029/2004WR003133

Salvadori G, De Michele C, Durante F (2011) On the return period and design in a multivariate framework. Hydrol Earth Syst Sci 15:3293-3305. https://doi.org/10.5194/hess-15-3293-2011

Salvadori G, Durante F, Michele CD, Bernardi M, Petrella L (2016) A multivariate copula-based framework for dealing with hazard scenarios and failure probabilities. Water Resour Res 52:3701-3721. https:// doi.org/10.1002/2015WR017225

Scorzini R, Frank E (2015) Flood damage curves: new insights from the 2010 flood in Veneto, Italy. J Flood Risk Manag. https://doi.org/10.1111/jfr3.12163

SEC (2010) 2010 Risk assessment and mapping guidelines for disaster management, Commission Staff Working Paper SEC 1626 Final, European Commission

Sesana E, Gagnon AS, Bertolin C, Hughes J (2018) Adapting cultural heritage to climate change risks: Perspectives of cultural heritage experts in Europe. Geosci 8:1-23. https://doi.org/10.3390/geoscience s8080305

Shahri AA, Spross J, Johansson F, Larsson F (2019) Landslide susceptibility hazard map in southwest Sweden using artificial neural network. CATENA 183:104225. https://doi.org/10.1016/j.catena.2019. 104225,2019

Shahri AA, Moud FM (2021) Landslide susceptibility mapping using hybridized block modular intelligence model. Bull Eng Geol Environ 80:267-284. https://doi.org/10.1007/s10064-020-01922-8

Schmidt J, Matcham I, Reese S et al (2011) Quantitative multi-risk analysis for natural hazards: a framework for multi-risk modelling. Nat Hazards 58:1169-1192. https://doi.org/10.1007/s11069-011-9721-z

SISMED (2016) Modelli sperimentali di valutazione della vulnerabilità sismica di aree urbane complesse: il caso della città di Firenze. Responsabile scientifico DST M. Ripepe, DIDA M. De Stefano, DISIA B. Bertaccini. Finanziato da Ente Cassa di Risparmio di Firenze (in Italian)

Sklar A (1959) Fonctions de répartition à $\mathrm{n}$ dimensions et leurs marges. Publ Inst Statist Univ Paris $8: 229-231$

Stucchi M, Meletti C, Montaldo V, Akinci A, Faccioli E, Gasperini P, Malagnini L, Valensise G (2004) Pericolosità sismica di riferimento per il territorio nazionale MPS04. Istituto Nazionale Di Geofisica e Vulcanologia (INGV). https://doi.org/10.13127/sh/mps04/ag,(inItalian)

Sutley EJ, van de Lindt JW, Peek L (2017) Multihazard analysis: integrated engineering and social science approach. J Struct Eng. https://doi.org/10.1061/(ASCE)ST.1943-541X.0001846

Terzi S, Tirresan S, Schneiderbauer S, Critto A, Zebisch M, Marcomini A (2019) Multi-risk assessment in mountain regions: a review of modelling approaches for climate change adaptation. J Environ Manag 232(15):759-771. https://doi.org/10.1016/j.jenvman.2018.11.100

Tilloy A, Malamud BD, Winter H, Joly-Laugel A (2019) A review of quantification methodologies for multi-hazard interrelationships. Earth-Sci Rev 196:102881. https://doi.org/10.1016/j.earscirev.2019. 102881

UNESCO (2015) World Heritage: Fostering Resilience. Towards Reducing Disaster Risks to World Heritage, Paris 2015, available at http://en.calameo.com/read/00332997281ba181741f8

UNDRR (2015) Sendai Framework for disaster risk reduction 2015-2030. Online https://www.undrr.org/ publication/sendai-framework-disaster-risk-reduction-2015-2030. Last access 10-12-20

UNISDR (2018) Economic losses, poverty and disasters 1998-2017, [available online https://www.unisdr. org/2016/iddr/IDDR2018_Economic\%20Losses.pdf. Last access 10-12-20

UNEP (1994) Agenda 21: Programme for action for sustainable development. Available online https://susta inabledevelopment.un.org/content/documents/Agenda21.pdf. Last access 10-12-20

USACE (1989) Expected annual flood damage computation [available online at https://www.hec.usace. army.mil/publications/ComputerProgramDocumentation/CPD-30.pdf] last access 2-5-21

Vannucci G, Gasperini P, Boccaletti M (1999) Microzonation of the City of florence by the analysis of the macroseismic data, 24a Assemblea EGS - NH, The Hague (L'Aja, The Netherlands), 19-23 April, Mapp in poster section, 1(IV), 841

Vicente R, Parodi S, Lagomarsino S, Varum H, Silva JARM (2011) Seismic vulnerability and risk assessment: case study of the historic city centre of Coimbra, Portugal. Bull Earthq Eng. https://doi.org/10. 1007/s10518-010-9233-3

Viglione A, Laio F, Claps P (2007) A comparison of homogeneity tests for regional frequency analysis. Water Resour Res 43:3. https://doi.org/10.1029/2006WR005095

Vojinovic Z, Hammond M, Golub D, Hirunsalee S, Weesakul S, Meesuk V, Medina N, Sanchez A, Kumara S, Abbott M (2016) Holistic approach to flood risk assessment in areas with cultural heritage: a practical application. Nat Hazards 81:589-616. https://doi.org/10.1007/s11069-015-2098-7 
Yousefi S, Pourghasemi HR, Emami SN et al (2020) A machine learning framework for multi-hazards modeling and mapping in a mountainous area. Sci Rep 10:12144. https://doi.org/10.1038/ s41598-020-69233-2

Ward PJ, Blauhut V, Bloemendaal N, Daniell EJ, De Ruiter CM, Duncan JM, Emberson R, Jenkins FS, Kirschbaum D, Kunz M, Mohr S, Muis S, Riddell G, Schäfer A, Stanley T, Veldkamp TIE, Winsemius HC (2020) Review article: natural hazard risk assessments at the global scale. Nat Hazards Earth Syst Sci 2020(20):1069-1096

Wieland M, Pittore M, Parolai S, Zschau J, Moldobekov B, Begaliev U (2012) Estimating building inventory for rapid seismic vulnerability assessment: towards an integrated approach based on multi-source imaging. Soil Dyn Earthq Eng 36:70-83

Publisher's Note Springer Nature remains neutral with regard to jurisdictional claims in published maps and institutional affiliations. 